\title{
Microbial Endophytes that Live within the Seeds of Two Tomato Hybrids Cultivated in Argentina
}

\author{
Silvina Marianela Yanil López ${ }^{1,4}$ (D), Graciela Noemi Pastorino $^{2}$, \\ Mario Emilio Ernesto Franco 1,4 (10), Rocio Medina ${ }^{1,4}$, César Gustavo Lucentini ${ }^{3,4}$, \\ Mario Carlos Nazareno Saparrat ${ }^{1}$ and Pedro Alberto Balatti ${ }^{3,4, * \text { (iD) }}$ \\ 1 Consejo Nacional de Investigaciones Científicas y Técnicas (CONICET), Godoy Cruz 2290, \\ Ciudad Autónoma de Buenos Aires C1425FQB, Argentina; smyld03@hotmail.com (S.M.Y.L.); \\ ernesfranco@hotmail.com (M.E.E.F.); rociomedinalp@gmail.com (R.M.); \\ masaparrat@yahoo.com.ar (M.C.N.S.) \\ 2 Facultad de Ciencias Agrarias y Forestales, Universidad Nacional de La Plata, Calle 60 y 119, La Plata 1900, \\ Argentina; gnpastorino@gmail.com \\ 3 Comisión de Investigaciones Científicas de la Provincia de Buenos Aires (CICBA), Calle 526 entre 10 y 11, \\ La Plata 1900, Argentina; lucentinicgustavo@gmail.com \\ 4 Centro de Investigaciones en Fitopatología (CIDEFI), UNLP; Calle 60 y 119, La Plata 1900, Argentina \\ * Correspondence: pbalatti@gmail.com; Tel.: +54-0221-423-6758
}

Received: 15 June 2018; Accepted: 31 July 2018; Published: 3 August 2018

\begin{abstract}
Tomato (Solanum lycopersicum L.) is probably the most important vegetable consumed around the world, and like other produce is affected by stresses and diseases that reduce the yield and production. The purpose of this work was to study the phytobiome of the tomato seeds of two hybrids in order to understand first of all whether tomato cultivars host similar groups of organisms, as well as their effect on the community structure, particularly of those microbes with the potential to promote growth and/or control plant pathogens. Different cultivars of tomato (genotypes) host significantly different endophytic communities, which is also reflected at the order level. These communities are particularly rich in spore-forming bacteria that have the ability either to promote plant growth or synthetize antimicrobial compounds that deter plant pathogens. We conclude that the seeds of the tomato cultivars Elpida and Silverio are sources of endophytic bacteria capable of synthetizing antifungal substances that could potentially be used for biocontrol against plant-pathogenic fungi.
\end{abstract}

Keywords: endophytes; tomato; biocontrol; PGPB; seed; microbiome

\section{Introduction}

Tomato (Solanum lycopersicum L.) is probably the most important vegetable in terms of production and consumption around the world [1]. As in the case of other plants, the tomato genome is complemented by a plethora of genes provided by organisms associated both with surfaces as well as intracellular spaces, which is now known as the phytobiome [2-4]. The insurmountable amount of genes and proteins provided by these organisms is such that they are considered parts of the plant genomes, since they have a dramatic impact on the quality and production of different crops [5].

Research on sustainable management technologies alternative to chemical compounds, such as biofertilizers and biopesticides, has gained importance. Such technologies use as their main source the organisms identified within the bacterial communities that are associated with plants, known as the microbiome, to select organisms or groups of organisms to promote plant growth and/or protect plants against stresses, including pathogens [6,7]. In recent years, tens of thousands of microorganisms associated with plants that promote the growth or health of plants have been 
isolated [5-7]. The best-studied and most abundant organisms isolated from plant tissues belong to Actinobacteria, Proteobacteria and Firmicutes, and include members of the genera Streptomyces, Pseudomonas, Azoarcus, Enterobacter, Burkholderia, Stenotrophomonas and Bacillus, among others [8].

The diverse array of microbial communities within the tissues of plant organs have been defined as endophytes [2]. It is widely known that these microorganisms are colonizers of plants and, therefore, have a marked influence on plant health and productivity [9]. Endophytes may benefit hosts through diverse mechanisms, such as molecules that increase their capacity to compete for space, nutrients and/or ecological niches, the synthesis of antimicrobial substances or the synthesis of inducers of plant growth, or compounds like phytohormones and peptides that might keep vegetables or plant organs healthy, which additionally might have no negative effects on consumers and/or the environment [10-15].

The organisms can be transmitted once sexual reproduction has occurred, move within plants and survive with low water contents. Seeds might be the main source of endophytes, most seeds carry a diverse array of endophytes, which is not surprising considering that seeds represent a fundamental part of the life cycle of spermatophytes. Endophytes might be able to survive for a long time in dormant seeds and whenever the environmental conditions are amenable to seed germination, the newly developed plant (seedling) must host these organisms [16]. Seed endophytes are transmitted to the following generations, which means that throughout evolution the microbiome of plants might become indispensable to the completion of their life cycle. This transmission from generation to generation should select in favor of mutualistic relations that promote plant growth rather than pathogenic microbes, since these endosymbionts depend on their host for survival and reproduction $[17,18]$. Due to this, it is critical to understand which are the bacterial communities associated with plants and how these endophytic populations affect their growth, health and ability to survive in stressful environments. Interestingly, there are not as many studies looking at the bacteria associated with seeds as at rhizospheric bacteria $[13,19]$. Xu et al. [20] isolated 84 endophytic bacteria from tomato seeds and proved that the endophytic community structure is a function of the seed germplasm. The $16 S r D N A$ PCR-RFLP analysis showed that tomato seeds contained a quite diverse endophytic community of bacteria. Interestingly, all isolated bacteria were Bacillus, a genus within the phylum Firmicutes that under environmental stress forms endospores, which could be related to their ability to survive under dehydration and starvation $[13,21,22]$. The conditions prevailing during seed maturation vary throughout the process, which might affect bacterial survival within seeds. Seed endophytes share some characteristics that might not be typical of endophytes from other plant tissues $[13,22]$. Truyens et al. [22] analyzed several studies on seed endophytes and highlighted that the bacteria present in the seeds of many different plants mostly belong to Bacillus and Pseudomonas, and less frequently to Paenibacillus, Micrococcus, Staphylococcus, Pantoea and Acinetobacter. In any case, all these bacteria differ in their survival strategies.

Recently, a community analysis of culturable and unculturable microorganisms interacting with plants was performed by means of new generation sequencing technologies. In such studies, the phytobiome of tomato and sugarcane roots [23] were formed mainly by Actinobacteria, Proteobacteria, Bacteroidetes and Firmicutes [9,24]. It is interesting to highlight that Streptomycetales and Pseudomonadales were found to be the predominant organisms within tomato roots. Furthermore Burkholderiales, Xanthomonadales Micromonosporales, Rhizobiales, Sphingomonadales, and Flavobacteriales were also among the most abundant bacterial groups [23].

Culture-dependent experiments have provided an enormous amount of information about the beneficial effect of cultivable endophytic bacteria $[5,9,14]$, which was also confirmed when metagenomic and genomic studies were performed based on high-throughput sequencing. These studies provided information regarding the structure of these microbial communities and the ability of these organisms to adapt to different environments $[25,26]$.

The purpose of this work was to study the phytobiome of the tomato seeds from two hybrids in order to understand first of all whether tomato cultivars host similar groups of organisms, as well 
as their effect on the community structure, particularly that of those microbes with the potential to promote growth (PGPB - plant growth promoting bacteria) and/or control plant pathogens.

\section{Materials and Methods}

\subsection{Bacterial Community: Structure and Diversity}

Endophytic bacterial DNA from tomato was obtained from batches of 20 seeds of 2 cultivars Elpida F1 (Enza Zaden, Enkhuizen, The Netherlands) and Silverio (Syngenta-Rogers, Ciudad Autónoma de Buenos Aires, Argentina). Studies were performed with DNA isolated from three independent samples. Seeds were surface disinfected in 5\% commercial bleach and $0.01 \%$ Tween 20 for $10 \mathrm{~min}$ and rinsed 10 times with sterile distilled water. In order to check the efficiency of the procedure, an aliquot of the water used in the final wash was plated on tryptic soy agar (BritaniaLab S.A., Ciudad Autónoma de Buenos Aires, Argentina). Also, aliquots of this water were included in PCR reactions aimed at amplifying the $16 S \mathrm{rDNA}$ gene.

Surface sterile seeds of each cultivar were homogenized in $0.95 \%(w / v) \mathrm{NaCl}$, and the homogenate was filtered through filter paper to separate bacterial cells from seed debris. The filtrated aqueous homogenate was centrifuged $(10 \mathrm{~min} ; 15,000 \times g)$, and the pellet was used to isolate genomic DNA by means of the commercial kit Wizard ${ }^{\circledR}$ Genomic DNA Purification Kit (Promega, Madison, WI, USA) [27].

The $16 S$ rDNA gene V1-V3 region was amplified using 27F (5'-AGRGTTTGATCMTGGCT CAG-3') [28] and 519R (5'-GTNTTACNGCGGCKGCTG-3') primers [29], with a barcode on the forward primer for the MiSeq instrument (Illumina Inc., San Diego, CA, USA). PCR was performed using the HotStarTaq Plus Master Mix Kit (Qiagen, Germantown, MD, USA) under the following conditions: $94{ }^{\circ} \mathrm{C}$ for $3 \mathrm{~min}, 28 \mathrm{cycles}$ of $30 \mathrm{~s}$ at $94^{\circ} \mathrm{C}, 40 \mathrm{~s}$ at $53^{\circ} \mathrm{C}$ and $60 \mathrm{~s}$ at $72{ }^{\circ} \mathrm{C}$ and a final elongation step that consisted of $5 \mathrm{~min}$ at $72{ }^{\circ} \mathrm{C}$. PCR amplicons were resolved in $2 \%(w / v)$ agarose gel, where the size of the amplicon as well as the intensity of the bands were determined. Multiple samples based on their molecular weight and DNA concentrations were pooled together in equal proportions, and were purified by calibrated Ampure XP beads (San Francisco, CA, USA). Then, the pooled and purified PCR products were used to prepare the Illumina DNA library. Sequencing was performed at MR DNA (www.mrdnalab.com, Shallowater, TX, USA) on a MiSeq following the manufacturer's guidelines.

Mothur pipeline was used for the entire sequence data processing according to the Mothur SOP [30]. Errors were removed by screening those sequences that did not align with the Silva database (nr v119) [31], pre-clustering to merge rare sequences into larger sequences was performed according to the procedure described by Allen and co-workers [32]. Chimeras were removed by using uchime (UCHIME) [33]. Taxonomic classification was assigned by alignment with mothur's implementation of the SILVA database, followed by non-bacterial sequence removal. Singletons sequences, that is, those that occurred only once among all samples were removed. The final sequence data were grouped into operational taxonomic units (OTUs) divided by a genetic distance of $3 \%$ using the average neighbor method. Hill numbers, ${ }^{0} \mathrm{H}$ (richness), ${ }^{1} \mathrm{H}$ (diversity) and ${ }^{2} \mathrm{H}$ (equitability) were used to compare bacterial alpha diversity $[34,35]$ and were calculated using Mothur software (version 1.35.1, University of Michigan, Ann Arbor, MI, USA) [30].

\subsection{Isolation of Bacteria from Tomato Seeds}

Endophytic bacteria from tomato were isolated from seeds and seedling of 2 cultivars, Elpida F1 (Enza Zaden) and Silverio (Syngenta-Rogers), by culturing them on three different commercial culture media (TSA, Nutritive agar and King B; BritaniaLab S.A.).

Seeds were surface sterilized as described above. The effect of the sterilization procedure was confirmed by placing sterilized seeds on culture media. In order to generate axenically grown seedlings, seeds were surface sterilized and were seeded in glass tubes $(25 \mathrm{~cm}$ high and $3 \mathrm{~cm}$ in diameter) containing a sterile semisolid Hoagland solution $\left(8 \mathrm{~g} \mathrm{~L}^{-1}\right.$ agar). Tubes were incubated at $30^{\circ} \mathrm{C}$ and 
with a $16 \mathrm{~h}$ photoperiod for 30 days. Tomato seedlings 30 days old were harvested and surface sterilized as described above. Sterile seeds and seedlings of each tomato cultivar were crushed and homogenized in $3 \mathrm{~mL}$ of $3 \times$ Ringers solution ( $215 \mathrm{mg}$ of $\mathrm{NaCl}, 7.5 \mathrm{mg}$ of $\mathrm{KCl}, 12 \mathrm{mg}$ of $\mathrm{CaCl}_{2} \cdot 2\left(\mathrm{H}_{2} \mathrm{O}\right)$, $50 \mathrm{mg}$ of $\mathrm{Na}_{2} \mathrm{~S}_{2} \mathrm{O}_{3} \cdot 5\left(\mathrm{H}_{2} \mathrm{O}\right)$ in $100 \mathrm{~mL}$ of distilled water, $\mathrm{pH}$ adjusted to 6.6). Aliquots of the supernatant $(100 \mu \mathrm{L})$ were plated on the three media and plates were incubated at $28^{\circ} \mathrm{C}$ for 5 days [36]. After the 5-day incubation period, colonies developed and were morphologically characterized in terms of size, shape and color and were sub-cultured until pure cultures were obtained. Then, isolated bacteria were grown in liquid medium until saturation and aliquots of these cultures were combined with glycerol to make a final concentration of $10 \%$ glycerol. The tubes were maintained at $-80^{\circ} \mathrm{C}$.

\subsection{Extraction of Total DNA, PCR Amplification and Sequencing of the $16 S$ rDNA Partial Gene}

DNA was extracted from endophytic isolates using the Wizard ${ }^{\circledR}$ Genomic DNA Purification Kit (Promega). Isolated bacteria were cultured in liquid media until their cell concentration was approximately $1 \times 10^{9}$ cells $\mathrm{mL}^{-1}$. Aliquots of these cultures were extracted by following the procedure recommended by the manufacturer. The quality and quantity of the isolated DNA was checked by electrophoresis in $0.7 \%$ agarose gels stained with ethidium bromide that included a control sample of known concentration.

Organisms were further characterized through fingerprinting by means of BOX-PCR using the universal BOXA1R primer (5'-CTACGGCAAGGCGACGCTGACG-3') [37]. PCR amplification and electrophoretic analysis were performed as described in López and Balatti [37]. All those bacterial cultures that had a unique fingerprint were selected for further analysis. They were identified by means of the $1500 \mathrm{bp}$ sequence coding for the $16 S \mathrm{rDNA}$. Such fragments were amplified by PCR in a thermocycler (MinicyclerTM, MJ Research Inc., Waltham, MA, USA), by means of primers 27F and 1492R [28]. The PCR products obtained were purified and sequenced. The $16 \mathrm{~S} r D N A$ gene sequences were deposited in the GenBank database under the accession numbers MG963203 to MG963224.

Sequence analysis and alignment were performed with the $16 \mathrm{~S}$ biodiversity tool Geneious R9 software. Species classification using $16 S \mathrm{rDNA}$ amplicon sequencing data from bacterial samples was performed using the cloud-based 16S rDNA biodiversity tool (Geneious version R9.0.5, Biomatters, Auckland, New Zealand, http://www.geneious.com) [38]. The taxonomic position of the isolates was assessed by performing a molecular phylogenetic analysis. Phylogenetic analysis was performed under the maximum-likelihood (ML) criteria.

\subsection{In Vitro Antagonism of Endophytic Bacteria towards Tomato Pathogens}

\subsubsection{In Vivo Bioassays of the Pathogen Inhibition Effects of Bacteria}

Bacterial isolates were cultured as previously described. The pathogens Alternaria alternata, Corynespora cassiicola and Stemphylium lycopersici (strains CIDEFI 209, CIDEFI 235, CIDEFI 234, respectively) were cultured on Glucose potato agar-APG (BritaniaLab S.A.).

In vivo antagonism assays were performed by testing the inhibitory effects of each of the 41 endophytic bacteria isolated from tomato seeds on pathogen growth. Bacterial striae were made on nutritive agar plates that were divided in three sections, in each of which different fungal isolates were plated. Simultaneously, $5 \mathrm{~mm}$ mycelial plugs cut from the edge of seven day-old cultures of the fungal strain were placed in the centre of each of the three sections of the plate. All the plates were incubated at $25^{\circ} \mathrm{C}$ for 5 days and the inhibitory activity was evaluated based on the inhibition of fungal growth. A positive response was the visible zone of inhibition around the fungus.

2.4.2. Inhibitory Activity of the Cell-Free Supernatant of Endophytic Bacteria against Fungal Pathogens

Six selected bacteria (E4, E7, E8, E9, S15 and SE37) and the Bacillus subtilis strain Er-S as control were cultured in liquid nutrient broth in a rotary shaker at $180 \mathrm{rev} \mathrm{min}^{-1}$ at $28^{\circ} \mathrm{C}$ in the darkness for $48 \mathrm{~h}$. Cell-free cultured supernatants were obtained by centrifugation at $6000 \times g$ for $20 \mathrm{~min}$, 
and filtered through $0.45 \mu \mathrm{m}$ and $0.22 \mu \mathrm{m}$ organic filter membranes $\left({ }^{\odot} \mathrm{GVS}\right)$. The antimicrobial activity of culture filtrates was evaluated based on their inhibitory activity on the growth of plant pathogens such as A. alternata, C. cassiicola and S. lycopersici, which were cultured as described above.

The inhibitory activity of the cell-free supernatant on mycelial growth was measured by adding extracts to agar plates $(1.5 \% w / v$ agar) containing nutrient agar to make a final concentration $1 \%, 10 \%$ and $20 \%$ cell-free extract $(v / v)$. Then, a $5 \mathrm{~mm}$ mycelial plug was placed in the center of the plate that was incubated at $25{ }^{\circ} \mathrm{C}$. After 4 days the fungal growth was measured. The inhibition activity was calculated with the formula: Inhibition $(\%)=[($ Growth in control - Growth in treatment $) /$ Growth in control] $\times 100$ [39].

\subsubsection{Effect of Volatiles from Endophytic Bacteria against Fungal Pathogens}

A bioassay was performed in sealed petri dishes using the method described by Baysal et al. [39], with some modifications. Briefly, $300 \mu \mathrm{L}$ of bacterial cultures were spread onto a sterile plate containing TYB medium (BritaniaLab S.A.). Five millimeters fungal mycelial plugs were then placed in the centre of another plate containing PDA [40]. Those plates containing mycelial plugs were inverted and placed on top of the plates containing bacterial cultures and were rapidly sealed with three layers of parafilm. The plates were incubated at $25{ }^{\circ} \mathrm{C}$ until the fungal mycelium of the controls extended throughout $3 / 4$ of the plate. The controls were mounted with plates containing uninoculated TYB medium. The diameter $(\mathrm{mm})$ of the fungal colony was measured.

\subsection{Bacterial Effect on Tomato Growth}

Seeds of tomato cv Elpida were grown in vitro in culture medium containing $4.4 \mathrm{~g} \mathrm{~L}^{-1}$ of MS Basal Salts, $15 \mathrm{~g} \mathrm{~L}^{-1}$ of sucrose, $7.5 \mathrm{~g} \mathrm{~L}^{-1}$ of agar, with a $\mathrm{pH}$ of 6 . Ten milliliters of medium were poured into culture tubes and then tomato seeds were sown and inoculated with a bacterial suspension. This was made by resuspending bacterial colonies in $50 \mathrm{mM} \mathrm{Na}_{2} \mathrm{HPO}_{4}$ (pH 7) to an optical density of $0.2(600 \mathrm{~nm})$, and $100 \mu \mathrm{L}$ of the suspension were injected onto each tube. Each treatment had ten replicates that were incubated for 30 days in a growth chamber with $50 \%$ relative humidity $(\mathrm{RH})$ and a $16 \mathrm{~h}$ photoperiod. At the time of harvest, plants were removing from the tubes, cleaned and their roots and shoots were placed in paper bags to dry in an oven at $60^{\circ} \mathrm{C}$ until constant weight. The dry weights of both plant organs were recorded and compared to those of uninoculated control plants. Similar assays was performed in plastic pots (2 l) filled with sterile vermiculite that were inoculated with a subset of isolates that promote the growth of plants in the first assay. The plants were grown under controlled conditions in the greenhouse at $24 \pm 2{ }^{\circ} \mathrm{C}, 50 \% \mathrm{RH}, 16 \mathrm{~h}$ photoperiod, and were watered with a Hoagland solution. The data were subjected to analysis of variance (ANOVA), followed by a comparison of multiple treatment levels, controlled using the Tukey test.

\subsection{Siderophore and Phytohormone Production and Phosphate Solubilization}

Siderophores production was evaluated qualitatively on plates using chrome azurol S (CAS) agar, as described by Alexander and Zuberer [41]. Siderophore-production was evidenced after a $24 \mathrm{~h}$ incubation period by the development of an orange halo around colonies within three replicates of each bacterium.

Phosphate solubilization was determined as described by Castagno et al. [42]. Bacterial isolates (16-h-old cultures) were spotted on plates containing National Botanical Research Institute phosphate growth medium (NBRIP) $\left(5 \mathrm{~g} \mathrm{~L}^{-1} \mathrm{MgCl}_{2} 6\left(\mathrm{H}_{2} \mathrm{O}\right), 0.25 \mathrm{~g} \mathrm{~L}^{-1} \mathrm{MgSO}_{4} 7\left(\mathrm{H}_{2} \mathrm{O}\right), 0.2 \mathrm{~g} \mathrm{~L}^{-1} \mathrm{KCl}, 0.1 \mathrm{~g} \mathrm{~L}^{-1}\right.$ $\left(\mathrm{NH}_{4}\right)_{2} \mathrm{SO}_{4}, 5 \mathrm{~g} \mathrm{~L}^{-1} \mathrm{Ca}_{3}\left(\mathrm{PO}_{4}\right)_{2}$ and $10 \mathrm{~g} \mathrm{~L}^{-1}$ glucose $)$ and incubated at $28{ }^{\circ} \mathrm{C}$ for $48 \mathrm{~h}$. Phosphate solubilization was determined by the development of a clear halo around bacterial colonies.

The production of Indoleacetic acid (IAA,) a phytohormone, was evaluated on agar plates (9-cm diameter) inoculated with toothpicks into a grid pattern within agar cultures. Grid plates consisted of replicate rows of several isolates per plate. Each inoculated plate was overlaid with an 82-mm-diameter disk of nitrocellulose membrane (Amersham). All plates were incubated until the colonies reached 
0.5 to $2 \mathrm{~mm}$ in diameter. After a $24-48 \mathrm{~h}$ incubation period, membranes were removed from the plates and were saturated with Salkowski reagent $\left(2 \% 0.5 \mathrm{M} \mathrm{FeCl}_{3}\right.$ in $35 \%$ perchloric acid) [43].

\subsection{Biofilm and Autoaggregation Assays}

Bacteria were grown in $2 \mathrm{~mL}$ nutrient broth at $28{ }^{\circ} \mathrm{C}$ for $24 \mathrm{~h}$, diluted $1 / 100$ in nutrient broth and incubated for $48 \mathrm{~h}$ under the same conditions. Bacterial suspensions ( $5 \mathrm{~mL}$ ) were then transferred into a glass tube and allowed to settle for $24 \mathrm{~h}$ at $4{ }^{\circ} \mathrm{C}$. The optical density of these suspensions at $630 \mathrm{~nm}\left(\mathrm{OD}_{\text {final }}\right)$ was measured. A control tube was vortexed for $30 \mathrm{~s}$ and the initial $\mathrm{OD}_{630 \mathrm{~nm}}\left(\mathrm{OD}_{\text {initial }}\right)$ was determined. The percentage of autoaggregation was calculated as follows: $100 \times\left[1-\left(\mathrm{OD}_{\text {final }} / \mathrm{OD}_{\text {initial }}\right)\right][44]$.

Biofilm formation was determined macroscopically by a quantitative assay that use a 96-well microtiter plate, whereby biofilms were stained with crystal violet (CV), as described by Sorroche et al. [44]. The $\mathrm{OD}_{560 \mathrm{~nm}}$ of the solubilized CV was measured with a MicroELISA Auto Reader (KartellTM, Fisher Scientific, Chicago, IL, USA). In parallel, sterile control cultures were made with nutritive broth.

Autoaggregation assays were performed six times. In the biofilm assays, each strain was plated onto at least 12 wells of each microtiter plate. The data were subjected to a one-way analysis of variance (ANOVA), followed by a comparison of multiple treatment levels, controlled using the Tukey test. All statistical analyses were performed using Infostat (version 1.0, UNC, Cordoba, Argentina).

\section{Results}

\subsection{Bacterial Community}

\subsubsection{Total Bacterial Community Structure and Diversity}

We successfully disinfested the seed surface, which was demonstrated in two different ways. First, no bacteria developed on plates inoculated with the water used to wash seeds after sterilization, and second no PCR product was obtained when the reactions used this water for reactions.

The V1-V3 region of the 16S rDNA gene of two biological DNA-seed samples from two cultivars of tomato (Elpida and Silverio) on the MiSeq platform was amplified and sequenced. The sequence data used in this study were deposited in the NCBI Sequence Read Archive (SRA, www.ncbi.nlm.nih. gov/sra) and are available with the accession number PRJNA438294.

Sequencing data analysis and statistical inference from the samples provided up to 362,180 sequences (72,886 and 102,194 for Elpida seed and 89,848 and 97,252 for Silverio seed), which resulted in 47,323 useful $16 S$ rDNA sequences after the trimming process (13\% of initial sequences) (Table 1 ). The number of sequences of all treatments was normalized to the smallest number of sequences obtained from the Elpida seeds, which was 10,254. The Good's coverage was used as an index of the quality of the sequencing process, which was greater than $86 \%$ for trimmed and normalized data from all systems. These results suggest that probably not all microbes are represented in the analysis. The diversity and richness indices [34] of the samples studied suggest that Silverio seeds had a bacterial community with a larger richness $\left({ }^{0} \mathrm{H}\right)$ than Elpida seeds, although with similar species diversity $\left({ }^{1} \mathrm{H}\right)$. Also, in both communities; the most common species slightly prevailed $\left({ }^{2} \mathrm{H}\right)$, resulting in an unequal assemblage of the community. Figures 1 and A1 (Appendix A) show the taxonomic profiles of the bacterial community found for each germplasm of tomato at the phylum and genera level with the relative abundance $(>0.5 \%)$. The genus with relative abundance $<0.5 \%$, were grouped in "Others" (Figure A1 in Appendix A). 
Table 1. Average diversity estimates of the different communities studied.

\begin{tabular}{ccccc}
\hline Sample & Total Sequences & ${ }^{\mathbf{0}} \mathbf{H}$ & ${ }^{\mathbf{1}} \mathbf{H}$ & ${ }^{2} \mathbf{H}$ \\
\hline Elpida seed & 11,495 & 35,147 & 3.6 & 1.37 \\
Silverio seed & 12,167 & 62,867 & 3.7 & 1.39 \\
\hline
\end{tabular}

Hill numbers, ${ }^{0} \mathrm{H}$ (richness), ${ }^{1} \mathrm{H}$ (diversity) and ${ }^{2} \mathrm{H}$ (equitability). The seed endophytic bacteria of both tomato cultivars were mainly represented by four phyla (Figure 1). In this regard, Firmicutes made up $50 \%$ of the endophytic community of Elpida seeds, followed by Proteobacteria (28\%), Actinobacteria $(20 \%)$, and also including a small proportion of Bacteroidetes $(2 \%)$. The latter were reported as the smallest bacterial community component on Silverio seeds. Proteobacteria $(45 \%)$ and Actinobacteria $(48 \%)$ were the main components of Silverio seeds, while Firmicutes were represented at a smaller level $(5 \%)$ in this community (Figure 1). Among the Proteobacteria, Gammaproteobacteria was the most abundant class of the endophytic community of tomato Elpida and Silverio, $82 \%$ and $66 \%$, respectively. Alphaproteobacteria and Betaproteobacteria only represented $15 \%$ and $3 \%$ of the endophytic bacteria in Elpida and $27 \%$ and $7 \%$ in Silverio seed samples.

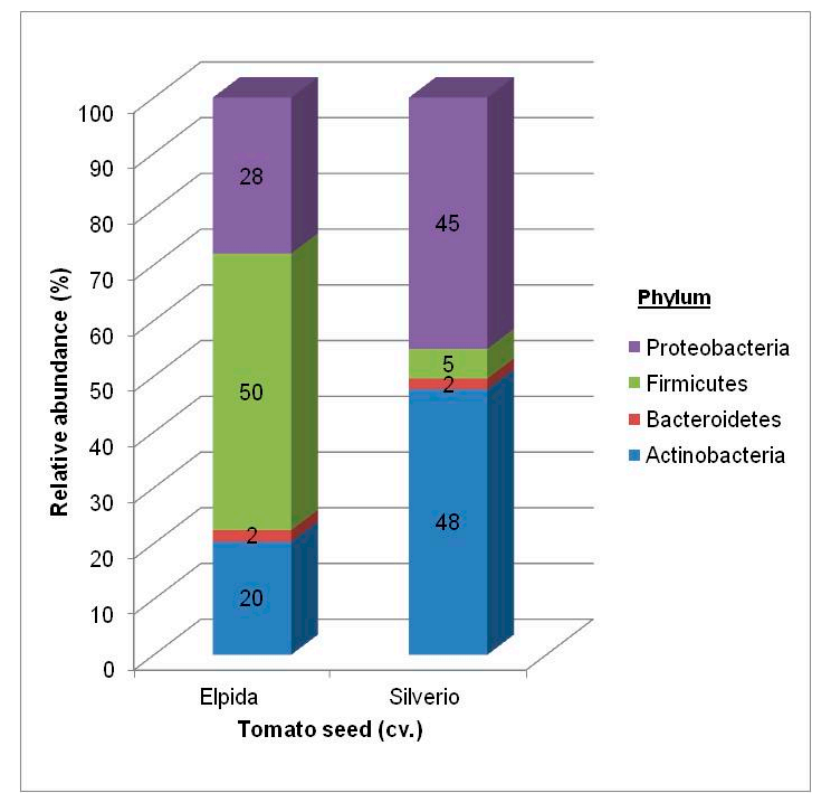

Figure 1. Taxonomic profiles of the bacterial community in each system at the phylum level with the relative abundance $(>0.5 \%)$.

The composition of the endophytic communities of the seeds of the tomato cultivar Elpida and Silverio were significantly different at the order level (Table 2). Actinomycetales (14.3\%), Bacillales $(63.3 \%)$ and Pseudomonadales (14.6\%) were the most abundant orders in Elpida seeds, whereas Actinomycetales (27.3\%), Rhizobiales (16\%) and Pseudomonadales (37.3\%) were the most abundant in the seeds of the cultivar Silverio. However, the genus composition of these orders was similar for both samples (Table 2). The Actinomycetales included mainly the genus Clavibacter, Corynebacterium, Micrococcus, Curtobacterium and Microbacterium in both seed cultivars. Pseudomonadales was found to contain OTUs assigned to the genus Moraxella, Pseudomonas and Acinetobacter; several others OTUs assigned to Bacillales and Rhizobiales were classified at the genus Paenibacillus, Staphylococcus, Shinella and Sphingobium. 
Table 2. The composition of the endophytic communities of Elpida and Silverio seed and seedling at the order and genus levels from the Illumina data set.

\begin{tabular}{|c|c|c|c|c|c|}
\hline Phyla & Class & $\begin{array}{c}\text { Order } \\
\text { Elpida Seed }\end{array}$ & $\begin{array}{c}\text { Genus } \\
\text { Elpida Seed }\end{array}$ & $\begin{array}{c}\text { Order } \\
\text { Silverio Seed }\end{array}$ & $\begin{array}{c}\text { Genus } \\
\text { Silverio Seed }\end{array}$ \\
\hline Actinobacteria & Actinobacteria & Actinomycetales $14.3 \%$ & $\begin{array}{c}\text { Clavibacter }(61 \%) \\
\text { Corynebacterium }(20 \%) \\
\text { Micrococcus }(11 \%) \\
\text { Curtobacterium }(6 \%) \\
\text { Microbacterium }(2 \%)\end{array}$ & Actinomycetales $27.3 \%$ & $\begin{array}{c}\text { Clavibacter }(81 \%) \\
\text { Corynebacterium }(6 \%) \\
\text { Micrococcus }(3 \%) \\
\text { Curtobacterium }(7 \%) \\
\text { Microbacterium }(3 \%)\end{array}$ \\
\hline \multirow{2}{*}{ Bacteroidetes } & Flavobacteria & Flavobacteriales $0.7 \%$ & Flavobacterium $(30 \%)$ & Flavobacteriales $1.3 \%$ & Flavobacterium (54\%) \\
\hline & Sphingobacteria & Sphingobacteriales $0.5 \%$ & Sphingobacterium $(100 \%)$ & Sphingobacteriales $1.7 \%$ & Sphingobacterium $(100 \%)$ \\
\hline Firmicutes & Bacilli & $\begin{array}{c}\text { Bacillales } 63.3 \% \\
\text { Lactobacillales } 0.5 \%\end{array}$ & $\begin{array}{l}\text { Paenibacillus }(92 \%) \\
\text { Staphylococcus }(8 \%)\end{array}$ & $\begin{array}{c}\text { Bacillales } 2.7 \% \\
\text { Lactobacillales } 0.7 \%\end{array}$ & $\begin{array}{l}\text { Paenibacillus (26\%) } \\
\text { Staphylococcus (74\%) }\end{array}$ \\
\hline \multirow{3}{*}{ Proteobacteria } & Alpha & $\begin{array}{c}\text { Rhizobiales } 2.7 \% \\
\text { Sphingomonadales } 0.7 \%\end{array}$ & $\begin{array}{c}\text { Shinella }(70 \%) \\
\text { Sphingobium }(15 \%) \\
\text { Rhizobium, Ensifer, Sinorhizobium (15\%) }\end{array}$ & $\begin{array}{c}\text { Rhizobiales } 16.0 \% \\
\text { Sphingomonadales } 3.3 \%\end{array}$ & $\begin{array}{c}\text { Shinella }(70 \%) \\
\text { Sphingobium }(15 \%) \\
\text { Rhizobium, Ensifer, Sinorhizobium (15\%) }\end{array}$ \\
\hline & Beta & Burkholderiales $0.5 \%$ & $\begin{array}{c}\text { Achromobacter }(20 \%) \\
\text { Acidovorax }(80 \%)\end{array}$ & Burkholderiales 5.0\% & $\begin{array}{c}\text { Achromobacter }(29 \%) \\
\text { Acidovorax }(71 \%)\end{array}$ \\
\hline & Gamma & $\begin{array}{l}\text { Enterobacteriales } 0.6 \% \\
\text { Pseudomonadales } 14.6 \%\end{array}$ & $\begin{array}{c}\text { Pantoea, Pectobacterium, Serratia }(3 \%) \\
\text { Pseudomonas }(75 \%) \\
\text { Moraxella }(14 \%) \\
\text { Acinetobacter }(8 \%)\end{array}$ & $\begin{array}{c}\text { Enterobacteriales } 4.0 \% \\
\text { Pseudomonadales } 37.3 \%\end{array}$ & $\begin{array}{c}\text { Pantoea, Pectobacterium, Serratia }(10 \%) \\
\text { Pseudomonas }(89 \%) \\
\text { Moraxella }(0.5 \%) \\
\text { Acinetobacter }(0.5 \%)\end{array}$ \\
\hline
\end{tabular}




\subsubsection{Culturable Bacterial Community}

A total of 41 isolates were obtained from seeds and tomato seedlings and analyzed by means of their BOX-PCR profiles (Figures A3 and A4 in Appendix A). A subset of 21 unique strains were assessed by comparing $16 \mathrm{~S} r \mathrm{DNA}$ sequences (E4, E6, E7, E8, E9, S15, S19, S20, S21, S26, S27, SE28, SE31, SE33, SE34, SE35, SE36, SE37, SS38, SS39 and SS41).

The taxonomic identity of 21 isolates was assessed by comparing $16 S r D N A$ sequences with those of references strains available at the Gene Bank database (Figure 2). The results were consistent with the clustering evidenced by the $16 \mathrm{~S}$ biodiversity graph (Figure A2 in Appendix A) that was generated with 16S Biodiversity tools of the Geneious software (Geneious version R9.0.5, Biomatters, http://www.geneious.com) (Table 3). It can be seen that Firmicutes were the most predominant class of microorganisms observed within the materials used in this study, with Bacillus and Paenibacillus being the most common genera. Also represented were the classes Alpha-Proteobacteria, Gamma-Proteobacteria and Actinobacteria (Figure A2).

Elpida seeds contained mainly Firmicutes (80\%) and Actinobacteria (20\%). From the seedlings of Elpida we also isolated in greater proportion representatives of Firmicutes and a smaller percentage of representatives of Actinobacteria and Gamma-Proteobacteria. The Actinobacteria isolated belonged to the genera Micrococcus and Microbacterium; isolates of the Gamma-Proteobacteria were representatives of the genus Acinetobacter.

When the sources of isolation were Silverio seeds, we again isolated mostly Firmicutes (67\%), and the $33 \%$ of Alpha-Proteobacteria was composed mainly of two different genera (Sphingomonas and Brevundimonas); whereas the bacteria isolated from the seedlings of this cultivar included only Firmicutes $(100 \%)$. The Firmicutes isolated from the seeds and seedlings belonged to the following genera: Bacillus, Paenibacillus, Psychrobacillus and Jeotgalibacillus.

After identification by $16 S \mathrm{SDNA}$ sequencing, the ability of the isolates to promote plant growth and antagonize A. alternata, C. cassiicola and S. lycopersici was evaluated.

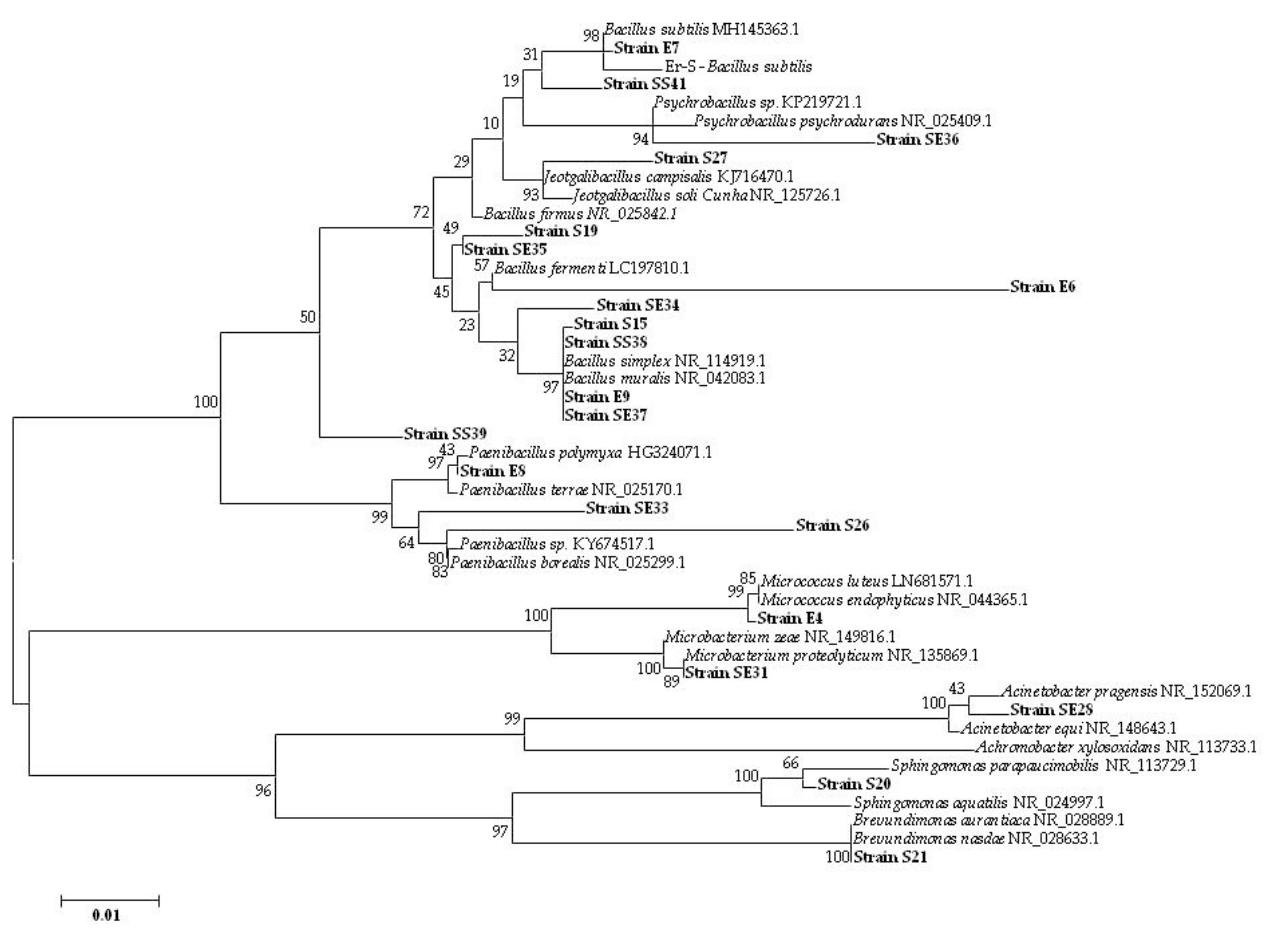

Figure 2. Maximum likelihood tree of endophytic bacteria inferred from the $16 S \mathrm{rDNA}$ data set. The sequences generated in this study are in bold type letter. The numbers at the nodes represent bootstrap support values as a percentage of 1000 replicates. The scale bar represents the average number of nucleotide substitutions per site. 
Table 3. Identification of endophytic bacteria from tomato seeds and seedling using sequences of the $16 S$ rDNA gene.

\begin{tabular}{ccc}
\hline Isolate (Origin) & $\begin{array}{c}\text { Closest Match in NCBI Database } \\
\text { (Accession Number) }\end{array}$ & Identity (\%) \\
\hline E4 (seed Elpida) & Micrococcus sp. (MG963203) & 99 \\
E6 (seed Elpida) & Bacillus sp. (MG963204) & 92 \\
E7 (seed Elpida) & Bacillus sp. (MG963205) & 99 \\
E8 (seed Elpida) & P. polymyxa (MG963206) & 99 \\
E9 (seed Elpida) & Bacillus sp. (MG963207) & 98 \\
S15 (seed Silverio) & Bacillus sp. (MG963209) & 99 \\
S19 (seed Silverio) & Bacillus sp. (MG963210) & 99 \\
S20 (seed Silverio) & Sphingomonas sp. (MG963211) & 96 \\
S21 (seed Silverio) & Brevundimonas sp. (MG963212) & 99 \\
S26 (seed Silverio) & Paenibacillus sp. (MG963213) & 91 \\
S27 (seed Silverio) & Jeotgalibacillus sp. (MG963214) & 99 \\
SE28 (seedling Elpida) & Acinetobacter sp. (MG963215) & 98 \\
SE31 (seedling Elpida) & Microbacterium sp. (MG963216) & 99 \\
SE33 (seedling Elpida) & Paenibacillus sp. (MG963217) & 99 \\
SE34 (seedling Elpida) & Bacillus sp. (MG963218) & 99 \\
SE35 (seedling Elpida) & Bacillus sp. (MG963219) & 99 \\
SE36 (seedling Elpida) & Psychrobacillus sp. (MG963220) & 97 \\
SE37 (seedling Elpida) & Bacillus sp. (MG963221) & 98 \\
SS38 (seedling Silverio) & Bacillus sp. (MG963222) & 99 \\
SS39 (seedling Silverio) & Bacillus sp. (MG963223) & 99 \\
SS41 (seedling Silverio) & Bacillus sp. (MG963224) & 96 \\
Er-S & B. subtilis (MG963208) & 99 \\
\hline
\end{tabular}

\subsection{In Vitro Antagonism of Endophytic Bacteria towards Tomato Pathogens}

\subsubsection{In Vivo Antagonism of Endophytic Bacteria towards Tomato Fungal Pathogens}

The biocontrol potential of 21 bacterial isolates was tested in Petri plates where fungal pathogens such as A. alternata, C. cassiicola and S. lycopersici were challenged with bacteria. The eleven bacterial isolates (E4, E6, E7, E8, E9, S15, S19, SE31, SE33, SE36, SE37 and Er-S) had an inhibitory effect on fungi, which was evidenced by a reduction in the colony diameter compared to the growth observed in control plants (Figure 3). Thus, these eleven endophytes were selected to evaluate their antagonist effect on the growth of fungal pathogens (Table 4).

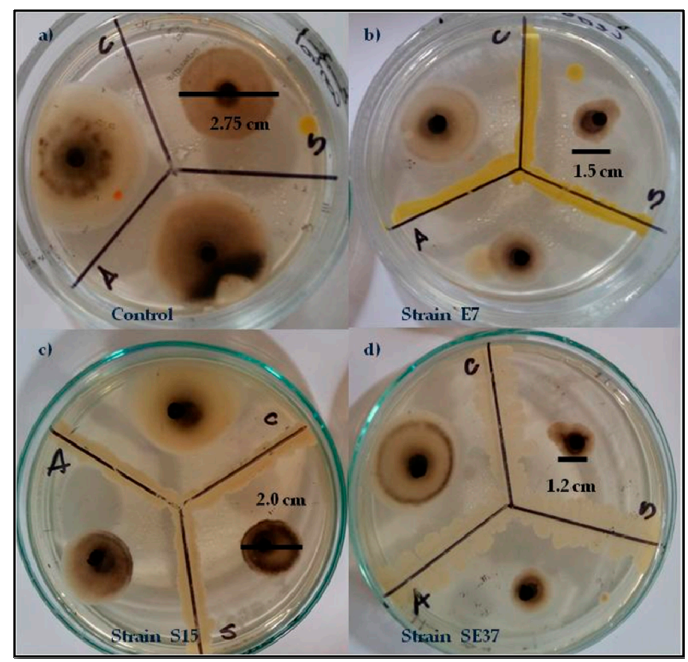

Figure 3. Antagonism effect of three endophytes of the seeds (b) E7, (c) S15 and (d) SE37; against three fungal pathogens of tomato in vitro: Alternaria alternata, Corynespora cassicola and Stemphylium lycopersici. (a) Plate control without inoculation. Bars indicate the diameter of the fungal colonies (cm). 
Among the evaluated endophytes, six provoked a major inhibition of fungal growth, they were E4 (Micrococcus sp.), E7 (Bacillus sp.), E8 (P. polymyxa), E9 (Bacillus sp.), S15 (Bacillus sp.) and SE37 (Bacillus sp.) and were selected to undergo antagonism assays (Table 4).

Table 4. Determination quantitative of the antagonist effect in the growth of fungi. Values from the same column followed by a letter in common are not significantly different according to Tukey's test at $p \leq 0.05$.

\begin{tabular}{cccc}
\hline Strain & A. alternata & C. cassiicola & S. lycopersici \\
\hline SE37 & $1.65 \pm 0.289 \mathrm{a}$ & $2.95 \pm 0.06 \mathrm{bc}$ & $1.4 \pm 0.231 \mathrm{a}$ \\
E4 & $2.05 \pm 0.289 \mathrm{ab}$ & $2.55 \pm 0.289 \mathrm{a}$ & $1.4 \pm 0.231 \mathrm{a}$ \\
E8 & $2 \pm 0.115 \mathrm{ab}$ & $2.8 \pm 0.115 \mathrm{ab}$ & $1.55 \pm 0.06 \mathrm{ab}$ \\
E7 & $2.35 \pm 0.173 \mathrm{bc}$ & $2.85 \pm 0.06 \mathrm{ab}$ & $1.85 \pm 0.06 \mathrm{bc}$ \\
Er-S & $2.45 \pm 0.404 \mathrm{bc}$ & $3 \pm 0.08 \mathrm{bc}$ & $1.9 \pm 0.115 \mathrm{bc}$ \\
S15 & $2.55 \pm 0.173 \mathrm{bc}$ & $3.25 \pm 0.289 \mathrm{c}$ & $2 \pm 0.115 \mathrm{~cd}$ \\
E9 & $2.75 \pm 0.289 \mathrm{~cd}$ & $2.7 \pm 0.115 \mathrm{ab}$ & $2.25 \pm 0.06 \mathrm{cde}$ \\
E6 & $2.9 \pm 0.115 \mathrm{cde}$ & $3.6 \pm 0.115 \mathrm{~d}$ & $2.35 \pm 0.404 \mathrm{def}$ \\
S19 & $2.9 \pm 0.08 \mathrm{cde}$ & $3.7 \pm 0.115 \mathrm{~d}$ & $2.6 \pm 0.115 \mathrm{efg}$ \\
SE31 & $3.15 \pm 0.289 \mathrm{def}$ & $3.7 \pm 0.115 \mathrm{~d}$ & $2.6 \pm 0.115 \mathrm{efg}$ \\
Control & $3.6 \pm 0.08 \mathrm{f}$ & $4.05 \pm 0.06 \mathrm{e}$ & $2.75 \pm 0.06 \mathrm{fg}$ \\
SE33 & $3.35 \pm 0.06 \mathrm{ef}$ & $4.05 \pm 0.06 \mathrm{e}$ & $2.9 \pm 0.115 \mathrm{~g}$ \\
SE36 & $3.25 \pm 0.289 \mathrm{def}$ & $4.3 \pm 0.08 \mathrm{e}$ & $2.95 \pm 0.06 \mathrm{~g}$ \\
\hline
\end{tabular}

\subsubsection{Effect of the Cell-Free Supernatant of Endophytic Bacteria against Fungal Pathogens}

We further evaluated the effect of cell-free supernatants from cultures of the endophytes E4, E7, E8, E9, S15 and SE37 against the growth of fungal pathogens such as A. alternata, C. cassiicola and S. lycopersici. The cell-free supernatants of the isolates E7 and Er-S effectively inhibited fungal growth (Figure 4). This inhibitory effect against C. cassiicola was linked to the concentration of the cell-free supernatants, since only when the concentration was above $1 \%$, did the culture supernatants inhibit the growth of C. cassiicola (Figure 4B).

The mycelial growth of Alternaria, Stemphylium and Corynespora was inhibited by cell-free supernatants of the isolate E7 by $80 \%, 75 \%$ and $27 \%$, respectively; while supernatants of Bacillus Er-S inhibited mycelial growth by $70 \%, 72 \%$ and $27 \%$, respectively (Figure $4 \mathrm{~A}-\mathrm{C}$ ). Interestedly, fungi exposed to culture supernatants presented morphological alterations such as wall thickness in the hypha and swollen mycelia.

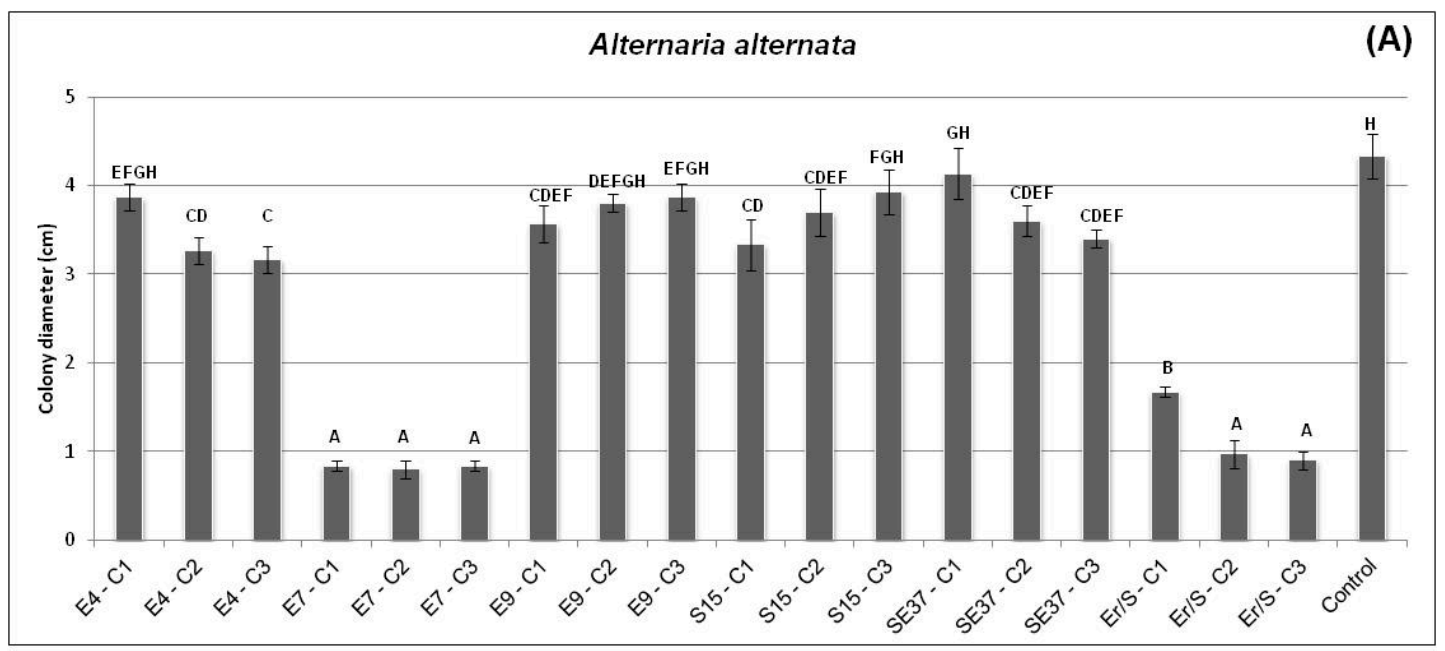

Figure 4. Cont. 

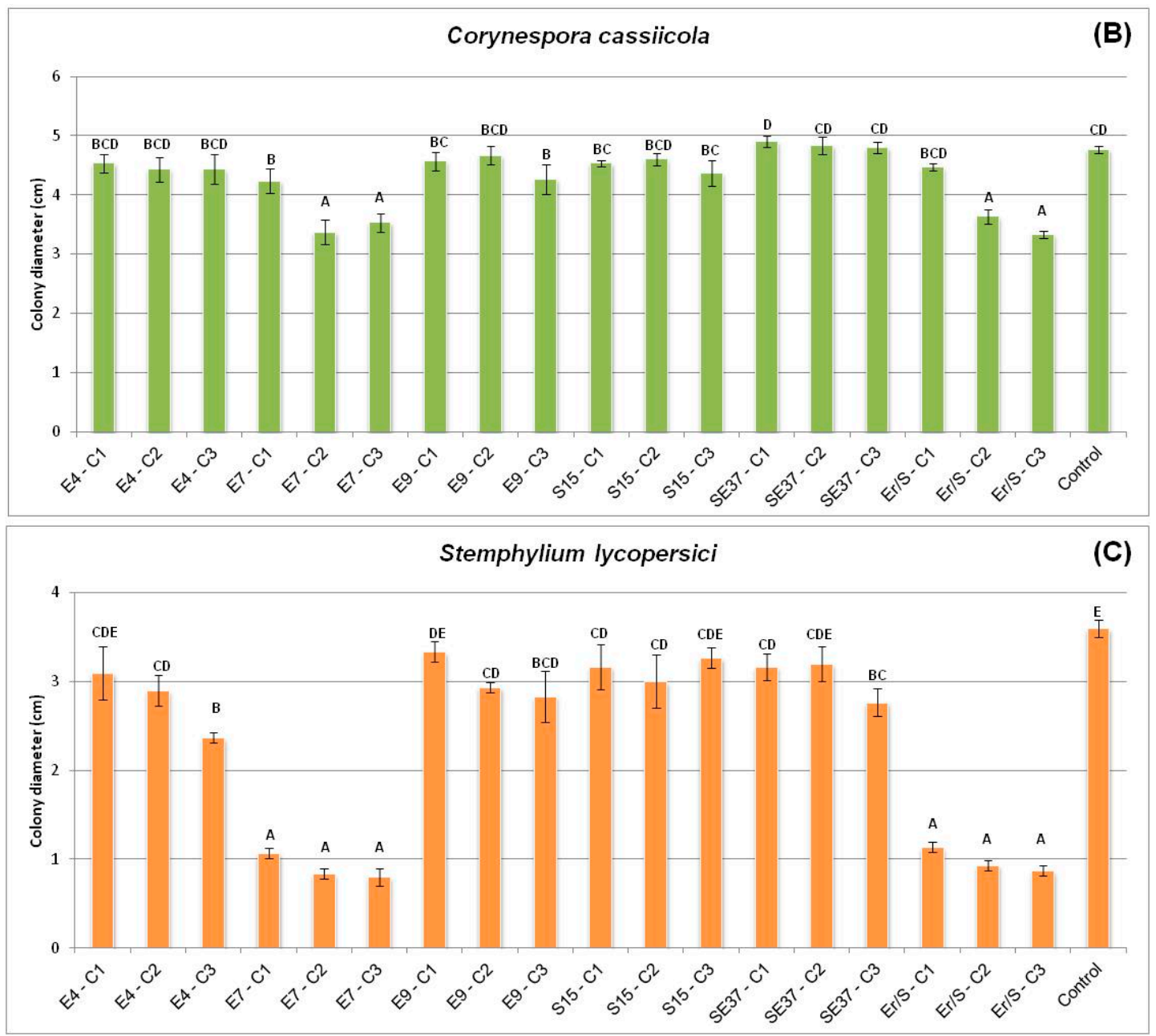

Figure 4. Inhibitory effect of the three concentrations, $1 \%, 10 \%$ and $20 \% v / v$, of cell-free supernatant of endophytic bacteria (E4, E7, E9, S15, SE37 and Er-S as control strain) against fungal pathogens: (A) A. alternata, (B) C. cassiicola, (C) S. lycopersici. Values are means of three independent biological replicates and error bars represent the standard deviation, letters in common on the bars are not significantly different according to the Tukey test at $p \leq 0.05$.

\subsubsection{Effect of Volatiles from Endophytic Bacteria on Fungal Pathogen Growth}

The isolates E7, E9, S15, SE37 and Er-S released antifungal volatile compounds (VOCs) that inhibited the growth of A. alternata, C. cassicola and S. lycopersici after a 72-144 h incubation period (Figure 5).

Isolates E7, E9, and Er-S, all identified as representatives of Bacillus sp., inhibited the growth of A. alternata by $68 \%, 51 \%$ and $82 \%$, respectively (Figure $6 \mathrm{~A}$ ). They also inhibited the growth of C. cassicola by $61 \%, 42 \%$ and $82 \%$, respectively (Figure $6 \mathrm{~B}$ ); and of $S$. lycopersici by $48 \%, 61 \%$ and $89 \%$, respectively (Figure 6C). 

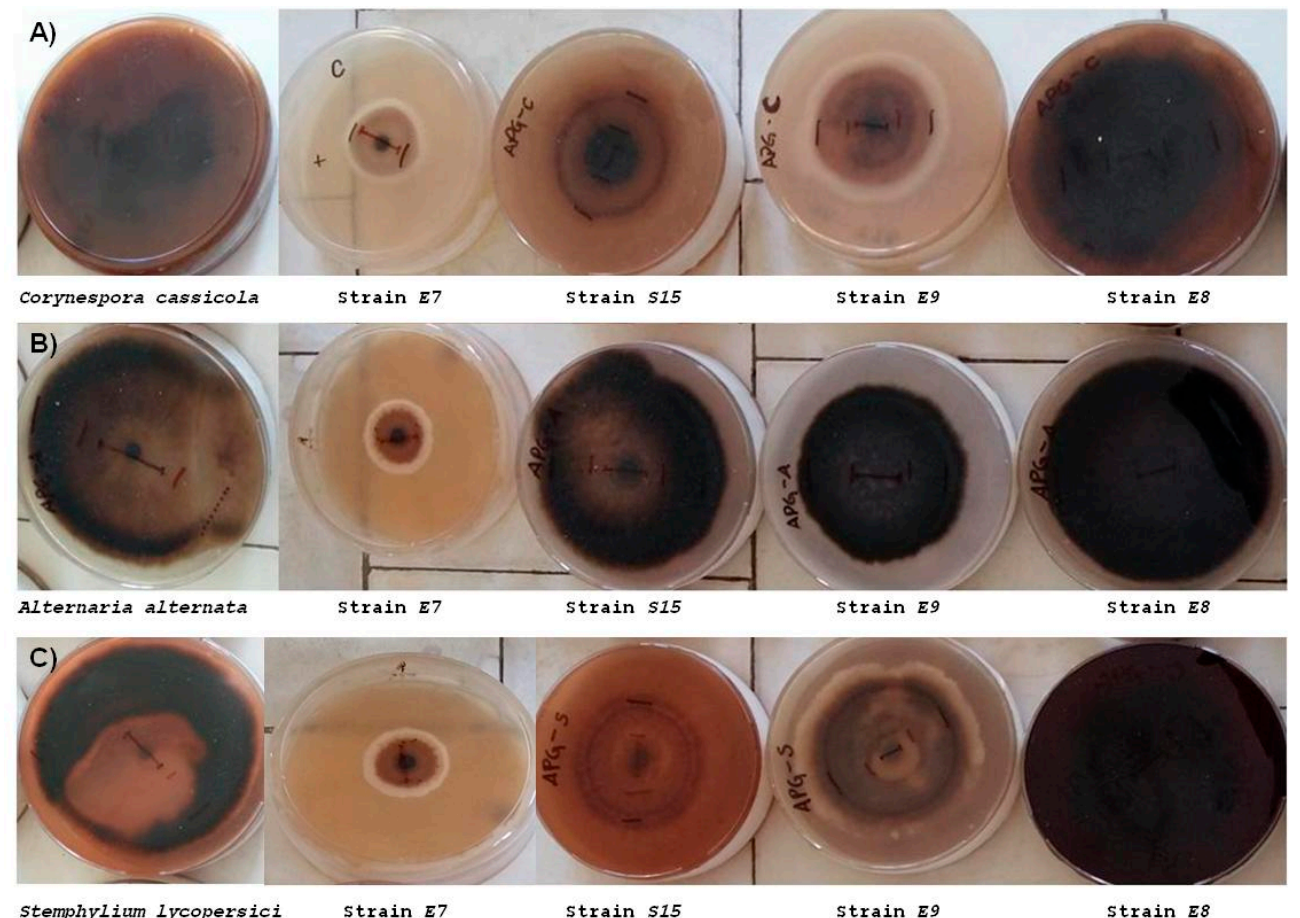

Figure 5. Effect on fungal pathogen growth of volatile compounds (VOCs) produce by endophytic bacteria, E7, S15, E9 and E8, against fungal pathogens: (A) C. cassiicola, (B) A. alternata, (C) S. lycopersici.

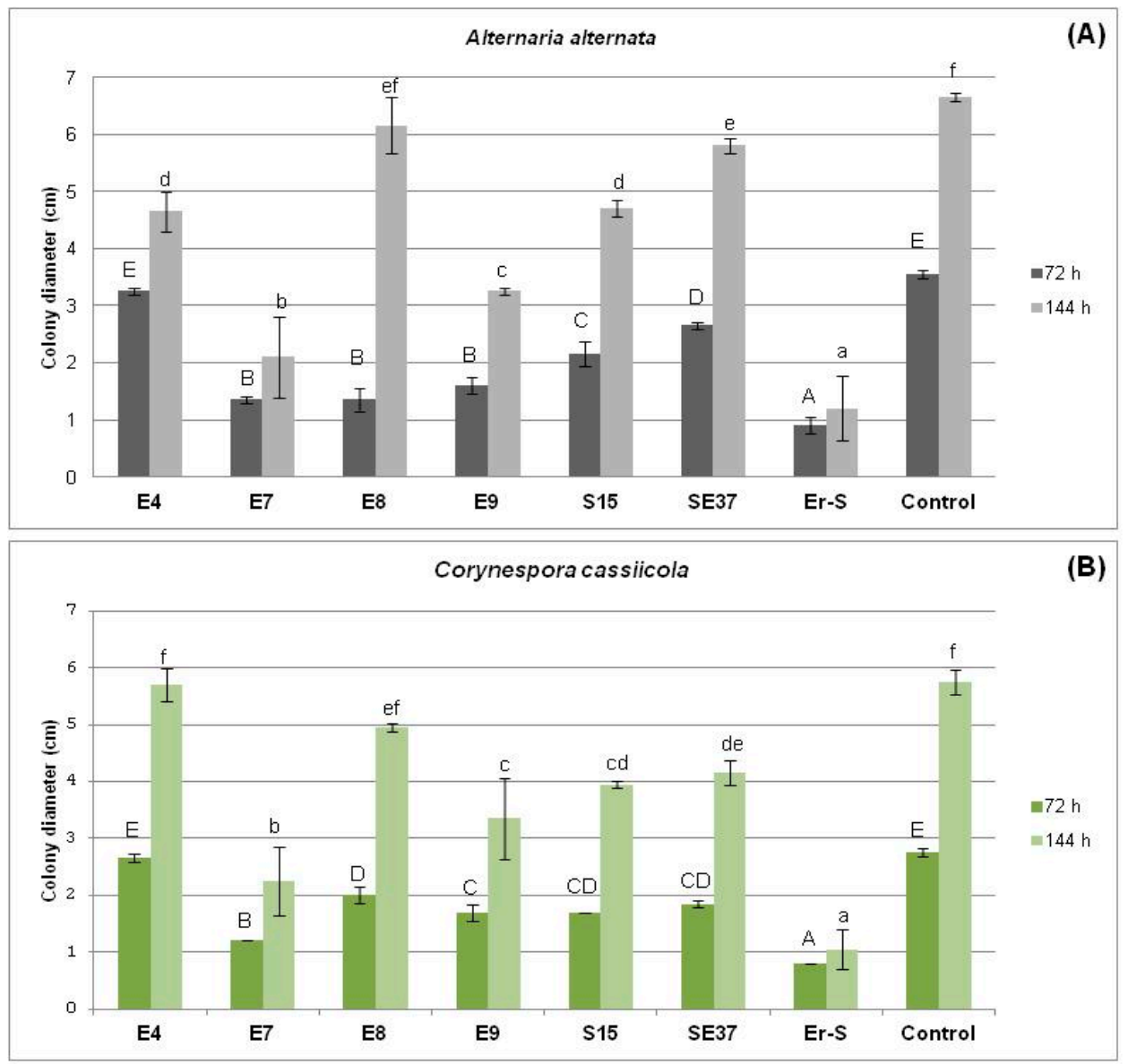

Figure 6. Cont. 


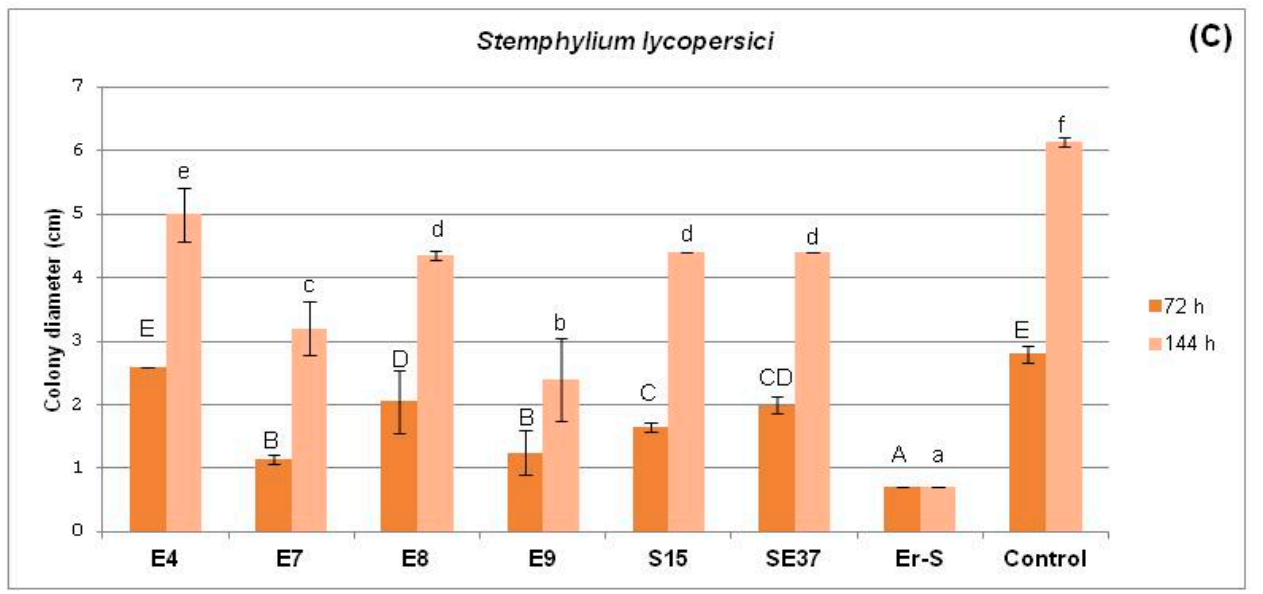

Figure 6. Antifungal activities of volatiles from endophytic bacteria (E4, E7, E8, E9, S15, SE37 and Er-S as control) against fungal pathogens: (A) A. alternata, (B) C. cassiicola and (C) S. lycopersici. Values are means of three independent biological replicates and error bars represent the standard deviation, letters in common on the bars are not significantly different according to the Tukey test at $p \leq 0.05$.

\subsection{Plant Growth Promotion Assays}

In order to determine whether endophytes of tomato seeds and seedlings have the potential to promote plant growth, the 21 taxonomically identified isolates were evaluated for their capacity to promote the growth of tomato plants in axenically-grown tomato plants. They were compared with the growth of un-inoculated controls and plants inoculated with P. fluorescens. Seedling length and dry weight were determined. These results provided the bases for the design of a new experiment in pots that included the isolates E4 (Micrococcus), E6 (Bacillus), E8 (P. polymyxa), S15 (Bacillus), S21 (Brevundimonas), SE28 (Acinetobacter), SE31 (Microbacterium), SE36 (Psychrobacillus), SS38 (Bacillus) and SS39 (Bacillus). We determined the root volume, dry root weight, as well as the shoot dry weight. As a positive control, a set of plants were inoculated with $P$. fluorescens.

Plants that had no pathogenic symptoms and that were inoculated with isolates E4, E6, E8, S15, SE31 and P. fluorescens had more roots, a higher root dry weight and root volume, as well as a higher shoot dry weight compared to the non-inoculated plants (Table 5). Plants inoculated with the isolate E6, SE31 and P. fluorescens had no effect on the volume and dry weight of the roots. Only two isolates, SS38 and SS39, promoted shoot growth, the rest of the isolates had no effect on plant growth (Table 5).

Table 5. Effect on tomato plant growth (dry and fresh root weight, dry air weight and root volume) produced by endophytic bacteria isolated from tomato seeds (E4, E6, E8, S15, S21) and seedlings (SE28, SS38, SS39). Values from the same column followed by a letter in common are not significantly different according to the Tukey test at $p \leq 0.05$.

\begin{tabular}{ccccc}
\hline Isolate & Fresh Weight Root $(\mathbf{g})$ & Root Volume (mL) & Dry Weight Root (g) & Dry Air Weight (g) \\
\hline Strain E4 & $5.09 \pm 0.7 \mathrm{a}$ & $4.57 \pm 0.5 \mathrm{ab}$ & $0.31 \pm 0.1 \mathrm{bc}$ & $0.59 \pm 0.1 \mathrm{cde}$ \\
Strain E6 & $5.43 \pm 0.8 \mathrm{a}$ & $5.44 \pm 0.6 \mathrm{a}$ & $0.38 \pm 0.1 \mathrm{ab}$ & $0.55 \pm 0.1 \mathrm{def}$ \\
Strain E8 & $5.10 \pm 0.6 \mathrm{a}$ & $5.06 \pm 0.8 \mathrm{a}$ & $0.35 \pm 0.1 \mathrm{ab}$ & $0.56 \pm 0.1 \mathrm{de}$ \\
Strain S15 & $5.59 \pm 0.3 \mathrm{a}$ & $5.56 \pm 0.4 \mathrm{a}$ & $0.44 \pm 0.0 \mathrm{a}$ & $0.57 \pm 0.1 \mathrm{cde}$ \\
Strain S21 & $3.64 \pm 0.3 \mathrm{bc}$ & $3.63 \pm 0.5 \mathrm{bcd}$ & $0.25 \pm 0.0 \mathrm{~cd}$ & $0.41 \pm 0.1 \mathrm{ef}$ \\
Strain SE28 & $2.36 \pm 0.4 \mathrm{~d}$ & $2.07 \pm 0.6 \mathrm{e}$ & $0.19 \pm 0.0 \mathrm{~d}$ & $0.52 \pm 0.1 \mathrm{ef}$ \\
Strain SE31 & $3.93 \pm 0.7 \mathrm{~b}$ & $3.44 \pm 0.5 \mathrm{~cd}$ & $0.38 \pm 0.1 \mathrm{ab}$ & $0.76 \pm 0.1 \mathrm{abc}$ \\
Strain SE36 & $3.29 \pm 0.2 \mathrm{bcd}$ & $3.38 \pm 0.5 \mathrm{~cd}$ & $0.25 \pm 0.0 \mathrm{~cd}$ & $0.74 \pm 0.1 \mathrm{bcd}$ \\
Strain SS38 & $3.26 \pm 0.5 \mathrm{bcd}$ & $3.50 \pm 0.5 \mathrm{~cd}$ & $0.28 \pm 0.1 \mathrm{bcd}$ & $0.86 \pm 0.1 \mathrm{ab}$ \\
Strain SS39 & $3.71 \pm 0.7 \mathrm{bc}$ & $3.50 \pm 0.7 \mathrm{~cd}$ & $0.26 \pm 0.1 \mathrm{~cd}$ & $0.94 \pm 0.2 \mathrm{a}$ \\
P. fluorescens & $4.01 \pm 0.7 \mathrm{~b}$ & $4.00 \pm 0.9 \mathrm{bc}$ & $0.29 \pm 0.1 \mathrm{bcd}$ & $0.84 \pm 0.2 \mathrm{ab}$ \\
Control & $2.96 \pm 0.3 \mathrm{~cd}$ & $2.84 \pm 0.2 \mathrm{de}$ & $0.19 \pm 0.0 \mathrm{~d}$ & $0.36 \pm 0.0 \mathrm{f}$ \\
\hline
\end{tabular}


The endophytes' ability to solubilize $\mathrm{P}$ and synthetize phytohormones and siderophores were also evaluated. Isolates E7, E8, S15, S19, S27, SE28, SE35, SE36, SE37 and SS38, produced IAA. Regarding siderophore production, isolates E7 and SE28 proved to synthetize such compounds and only isolate E7 solubilized P (Table 6).

Table 6. Indolacetic Acid (IAA) and siderophore production and phosphate solubilization.

\begin{tabular}{|c|c|c|c|c|}
\hline Isolate $^{1}$ & Source & IAA Production & Siderophore Production & Phosphate Solubilization \\
\hline E7 & \multirow{2}{*}{ Seeds Elpida } & + & + & + \\
\hline E8 & & + & & \\
\hline S15 & \multirow{3}{*}{ Seeds Silverio } & + & & \\
\hline S19 & & + & & \\
\hline S27 & & + & & \\
\hline SE28 & \multirow{4}{*}{ Seedling Elpida } & + & + & \\
\hline SE35 & & + & & \\
\hline SE36 & & + & & \\
\hline SE37 & & + & & \\
\hline SS38 & Seedling Silverio & + & & \\
\hline
\end{tabular}

The isolates that had the highest potential to promote plant growth (E4, E6, E8, S15 and SE31) were evaluated in terms of biofilm formation (biofilm and autoaggregation), since these characteristics might be indicative of the isolates having an outstanding colonization capacity.

The autoaggregation of bacteria behaved similarly to biofilm formation, in that the heterogeneity was quite high; while some strains strongly autoaggregated, others did not (Table 7).

Table 7. Biofilm and autoaggregation formation ability of endophytic bacteria with potential for plant growth promotion.

\begin{tabular}{ccc}
\hline Isolate & Biofilm $\left(\mathbf{O D}_{\mathbf{5 6 0 \mathbf { n m }}} / \mathbf{O D}_{\mathbf{6 3 0 n m}}\right)$ & Autoaggregation $\mathbf{( \% )}$ \\
\hline E4 & $0.38 \pm 0.02$ & $89.41 \pm 1.08$ \\
E6 & $13.58 \pm 0.62$ & 0 \\
E8 & $0.44 \pm 0.23$ & $34.16 \pm 2.33$ \\
S15 & $0.86 \pm 0.52$ & $38.14 \pm 1.55$ \\
SE31 & $5.00 \pm 0.26$ & 0 \\
PF & $2.51 \pm 0.26$ & $13.54 \pm 0.55$ \\
\hline
\end{tabular}

We performed a correlation analysis to determine whether the ability of the strains to autoaggregate and form biofilm was quantitatively related. A scatter plot was generated (Figure 7), and the Pearson correlation coefficient $(r)$ was calculated. We observed an inverse correlation between both phenotypes $(r \geq-0.64, p \leq 0.05)$, maybe because the cell interactions of the biofilm formation and aggregates were not determined equally on the same physical adhesive forces. 


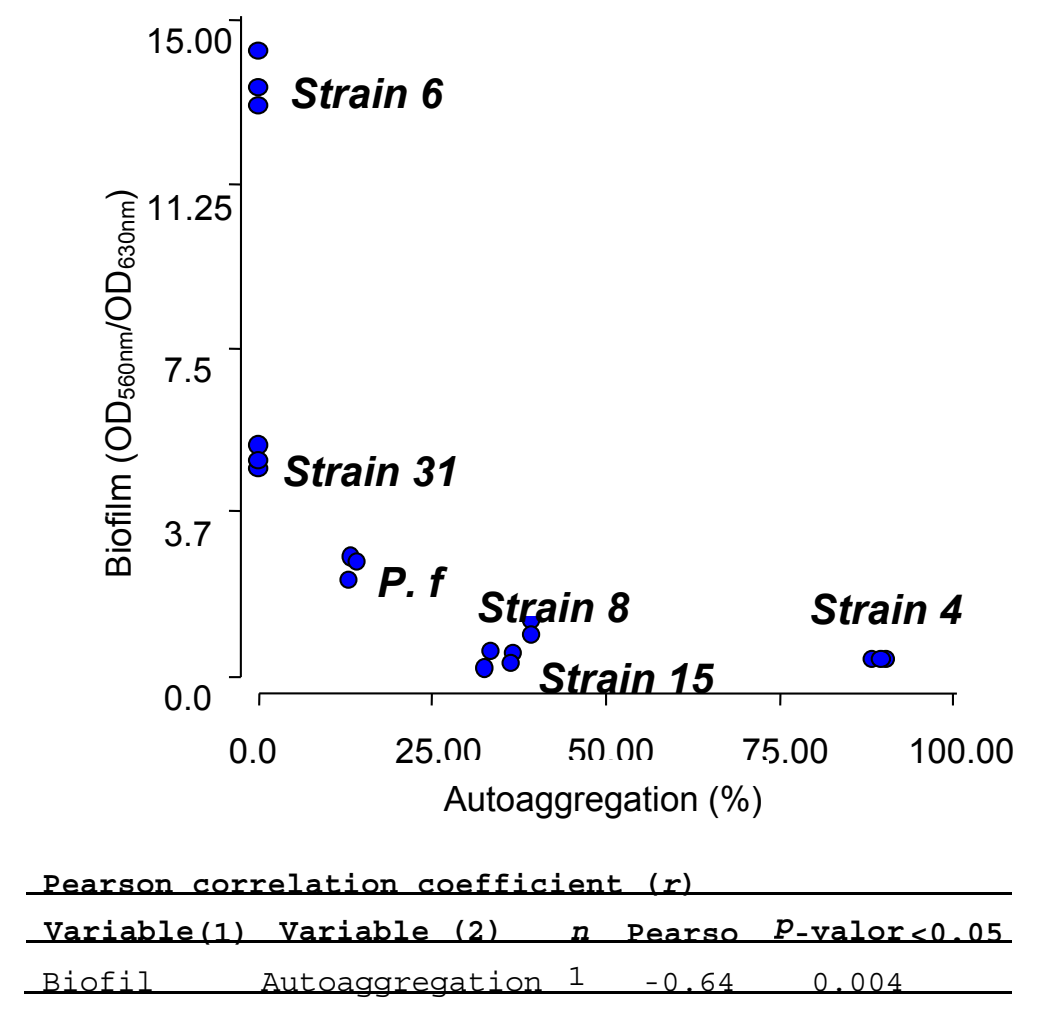

Figure 7. Scatter plot of two variables: biofilm formation ability $\left(\mathrm{OD}_{560 \mathrm{~nm}} / \mathrm{OD}_{630 \mathrm{~nm}}\right)$ and autoaggregation (\%). The Pearson correlation coefficient $(r)$ was calculated using Infostat, version 1.0.

\section{Discussion}

Endophytic bacteria are microorganisms that colonize and live within plant tissues intercellularly without affecting plant tissues [45]. Seeds are the main structure of plants that allow them not only to perpetuate in time, but are also the most efficient way for plants to withstand stresses; for this reason seeds play a key role in agriculture [46]. They are also the vehicle of a variety of pathogens and beneficial bacteria [16], whose growth occurs when seeds germinate. Such microbial communities are additionally $[47,48]$ enriched by the microorganisms that soils frequently provide. The study of bacteria within tomato seeds by metagenomic analysis and by isolating culturable endophytes showed that the number of bacterial species in the seeds of both cultivars of tomato was rather low, as in other plant species [49-52]. However, the cultivars Elpida and Silverio host significantly different endophytic communities regarding the composition at the level of order, suggesting that the plant genotype might provide a selection pressure on bacterial populations of endophytes. Simon et al. [53] also showed that the growth of both intrinsic bacteria and inoculated bacteria were different in tomato genotypes. Thus, even though seeds possess similar endophytic communities, our results confirmed that the plant genotype influences the structure of the endophytic bacterial community, which makes sense considering that each genotype might secrete a wide array of different nutrients and molecules to the apoplastic environment. Adams and Kloepper [54] evaluated whether the cotton plant genotype have an effect on the endophytic population of seeds, stems and roots. They showed that cotton plants not only have endophytic bacterial communities that change throughout the process of germination and seedling development, but also that cotton cultivars harbor different endophytic bacterial community structures.

The culturable bacteria isolated from the seeds and seedlings of both cultivars of tomato were similar regarding the phyla detected inside the seeds and seedlings. These suggest that tomato seeds might contain a basic subset of bacteria that probably enter seeds during the reproductive development, and that these bacteria most probably play specific roles either related to seed health 
or seedling growth. Firmicutes, the phylum that mostly colonize seeds, increased within seedlings, suggesting that seed germination somehow provides a nutritional advantage that enhances the growth of this group. Among the species found within seeds, some-like Bacillus, Paenibacillus, Psychrobacillus and Jeotgalibacillus - have the capacity to form endospores, which might explain their high frequency in seeds. Thus, the ability to form endospores seems to be a key characteristic of seed colonizers, since this contributes to their survival in seeds, regardless of whether they are stored for a short or long period of time $[22,50]$. We did not analyze the bacterial population of physiologically mature seeds immediately after development, but they might contain non-spore-forming bacteria that might make the bacterial population more diverse, though they probably die if seeds are stored with low water content. The seed maturation process probably do not select microorganisms based on their properties, but rather based on their diversity, or at least the diversity of the culturable microorganisms is determined by their ability to sporulate. Mano et al. [49] found that Gram-negative isolates predominated in the initial stages of seed development and that Gram-positive isolates appeared as seeds mature. In this regard, we isolated 18\% of Gram-negative (Sphingomonas and Brevundimonas) and $82 \%$ of Gram-positive bacteria from the seeds (Elpida and Silverio), while in the developed seedlings (Elpida and Silverio), $90 \%$ of the bacteria were Gram-positive species and only $10 \%$ were Gram-negative (Acinetobacter). Evidently, some changes occur during seedling development that promote certain groups of microorganisms [22]. Seed development might strongly require nutrients to generate in this way in a stressful environment for bacteria and, as result of this, probably only those able to sporulate survive this stringent environment well. Common bacterial genera found in seeds are Bacillus and Pseudomonas. Paenibacillus, Micrococcus, Staphylococcus, Pantoea and Acinetobacter have also been found to inhabit seeds $[19,20,22,49-52]$. Tomato seeds host endophytic bacterial communities, similar to those reported for other plant species, suggesting that that the presence of such bacterial communities are essential for plant growth, but also as inoculum, since seeds have a strategy of dispersion that might lead them to different environments.

Endophytes most probably provide benefits to host plants through several mechanisms, such as the synthesis of antimicrobial substances or the synthesis of plant growth promoters. Our results show that not all bacteria (E4, E7, E8, E9, S15 and SE37) inhibit mycelial growth under controlled conditions; however, they differ in their ability to synthesize some inhibitory molecules. Bacillus sp., E7 inhibited the growth of three soil-borne plant pathogens-A. alternata, C. cassicola and S. lycopersici-doing so by means of water soluble inhibitory products that are released into the culture medium, and also by the synthesis of VOCs. Thus, this bacterium has a different strategy, although we cannot assess which is the most important strategy in nature. Antifungal molecules synthesized by microorganism may be used to biocontrol microorganism [39]. Most of the biocontrol products synthesized by some species of Bacillus are small polypeptides, such as iturins and bacillomycins, that inhibit the growth of several fungi [39]. In this work, we found that Bacillus E 7, a species that colonizes tomato seedlings, proved to have an outstanding capacity to protect plants against fungal pathogens. It might be the case that the isolates can synthetize antimicrobial molecules like those mentioned above, we are currently analyzing this scenario.

Another potential role of microorganisms is to work as plant growth promoters, a characteristic shared by isolates E4 (Micrococcus), E6 (Bacillus), E8 (P. polymyxa), S15 (Bacillus) and SE31 (Microbacterium). Representatives of these genera that promote plant growth have already been found within plant tissues. Actinobacteria like Micrococcus and Microbacterium are frequently present within the rhizosphere of plants, suggesting that they play a crucial role and promote plant growth while interacting with plants [55]. Sangthong et al. [56] found that representatives of the Micrococcus sp. promoted the root and shoot length, as well as the shoot biomass of Zea mays L. The isolate proved to be a potent bioaugmenting agent, facilitating cadmium phytoextraction in Z. mays L. Prapagdee et al. [57] found that Microccocus sp. promoted growth and cadmium uptake by dicotyledonous plants in cadmium-polluted soil. In this work, we also found that Micrococcus and Microbacterium, E4 and SE31 respectively, promoted the root and shoot growth of tomato plants. Vílchez et al. [58] showed that in 
pepper plants Microbacterium sp. promoted an increase in sugar biosynthesis that probably provided the plants with a more efficient osmotic adjustment, relieving in this way the effect of stress on the host plants. Also, Microbacterium sp. protects plants against drought stress while living within them [58]. The plant growth promotion and protection effects of Bacillus and Paenibacillus are the result of several complex and interrelated processes that involve direct and indirect mechanisms such as nitrogen fixation, phosphate solubilization, siderophore and phytohormone production and the control of plant diseases [59-61]. In this work, bacteria were also found to play several different roles. Bacillus isolates E6 and S15 and P. polymyxa isolates E8 are plant growth promoters. Isolates S15 and E8 control the fungal pathogens of tomato. Such bacteria share groups of key features, like a high secretion capacity and spore formation capacity, which are critical features in terms of commercial applications, which require a long shelf life $[22,50,61]$.

One of the key steps while using bacteria as a biocontroller, is the effective colonization of plant roots, particularly to promote growth. Bacteria persist in natural environments by forming biofilms, which are communities of highly organized cells, joined to the surface and encased in a self-produced extracellular matrix [44,62]. We found these five isolates to be highly efficient in promoting plant growth that forms some type of biofilm, which might provide an adaptive advantage to colonizing plant tissues. Nevertheless, in some cases, such as P. polymyxa, biofilm development in the root tips was crucial for bacteria to penetrate intercellular spaces, however, the bacteria did not spread within plant tissues, suggesting that other crucial mechanisms are needed [62].

\section{Conclusions}

The community associated with seeds of different cultivars reflects their different resources and their potential to prevent the attack of pathogens and promote plant growth. The use of tools such as metagenomics allows us to know more about the communities associated with different cultivars; it has proven to be a useful technology. Different cultivars of tomato (genotypes) host significantly different endophytic communities, a fact which is also reflected at the order level. These communities are particularly rich in spore-forming bacteria, which have the ability either to promote plant growth or synthetize antimicrobial compounds to deter plant pathogens.

We conclude that the seeds of the tomato cultivars Elpida and Silverio are sources of endophytic bacteria capable of synthetizing antifungal substances that could potentially be used for biocontrol against plant-pathogenic fungi.

Author Contributions: S.M.Y.L. and G.N.P. conceived and designed the experiments; S.M.Y.L., G.N.P., C.G.L. and M.E.E.F. performed the experiments; S.M.Y.L. and R.M. analyzed the metagenomic data; M.C.N.S. and P.A.B. contributed reagents/materials/analysis tools; S.M.Y.L. and P.A.B. wrote the paper.

Funding: This research was funded by Agencia Nacional de Promoción Científica y Tecnológica (ANPCyT) of the Ministerio de Ciencia, Tecnología e Innovación Productiva through the projects PICT-2016-0794 Jóvenes Investigadores (Silvina López) and the CICBA through the Subsidio 2017 (Pedro Balatti) http:/ / www.agencia. mincyt.gob.ar; https:/ / www.gba.gob.ar/cic.

Acknowledgments: This research was partially supported by the Consejo Nacional de Investigaciones Científicas y Técnicas (CONICET), Agencia Nacional de Promoción Científica y Tecnológica (ANPCyT) of the Ministerio de Ciencia, Tecnología e Innovación Productiva through the projects PICT-2016-0794 Jóvenes Investigadores (Silvina López) and the CICBA through the Subsidio 2017 (Pedro Balatti).

Conflicts of Interest: The authors declare no conflict of interest. 


\section{Appendix A}

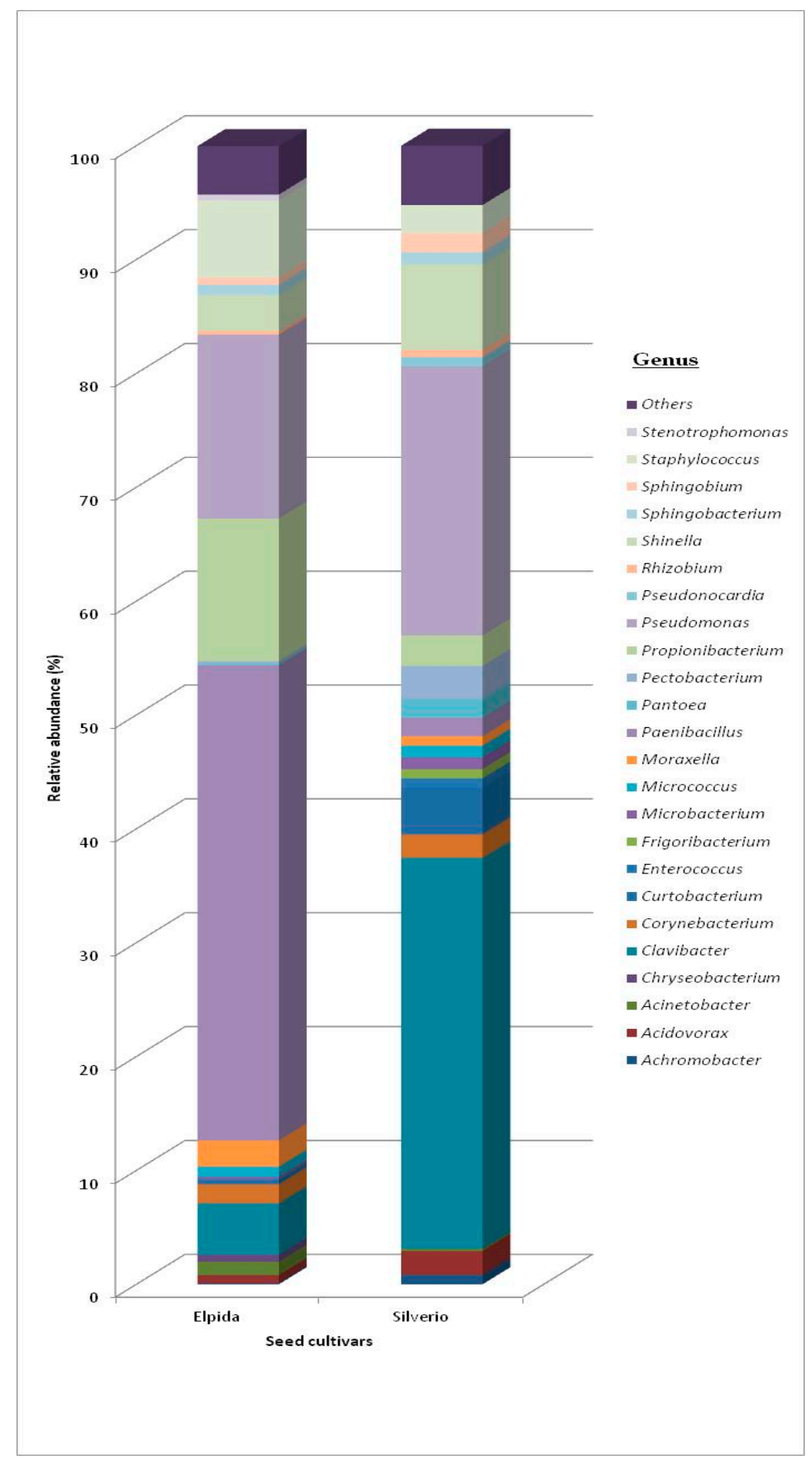

Figure A1. Taxonomic profiles of the bacterial community in each system at genus level with the relative abundance $(>0.5 \%)$. The genus with relative abundance $<0.5 \%$, were grouped in "Others". 


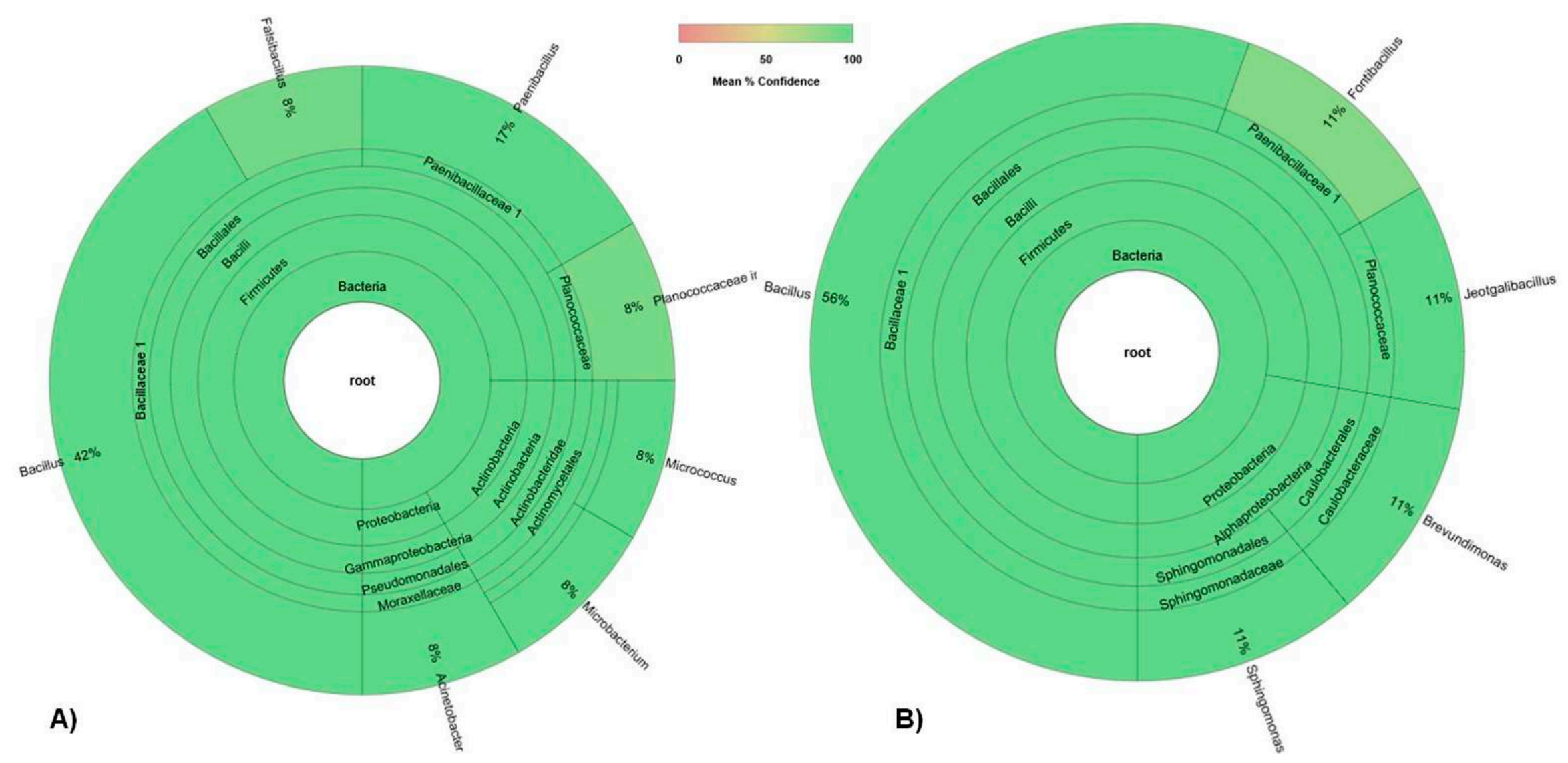

Figure A2. Comparison of bacterial species isolated from seeds and seedling of each tomato cultivar: (A) Elpida cultivar, (B) Silverio cultivar. 16S biodiversity graph generated with 16S Biodiversity tools of Genious software (version R9.0.5, Biomatters, http:/ /www.geneious.com). 
A total of 41 isolates were obtained from seed and tomato seedlings and were characterized according to their BOX-PCR profiles (Figures A3 and A4).

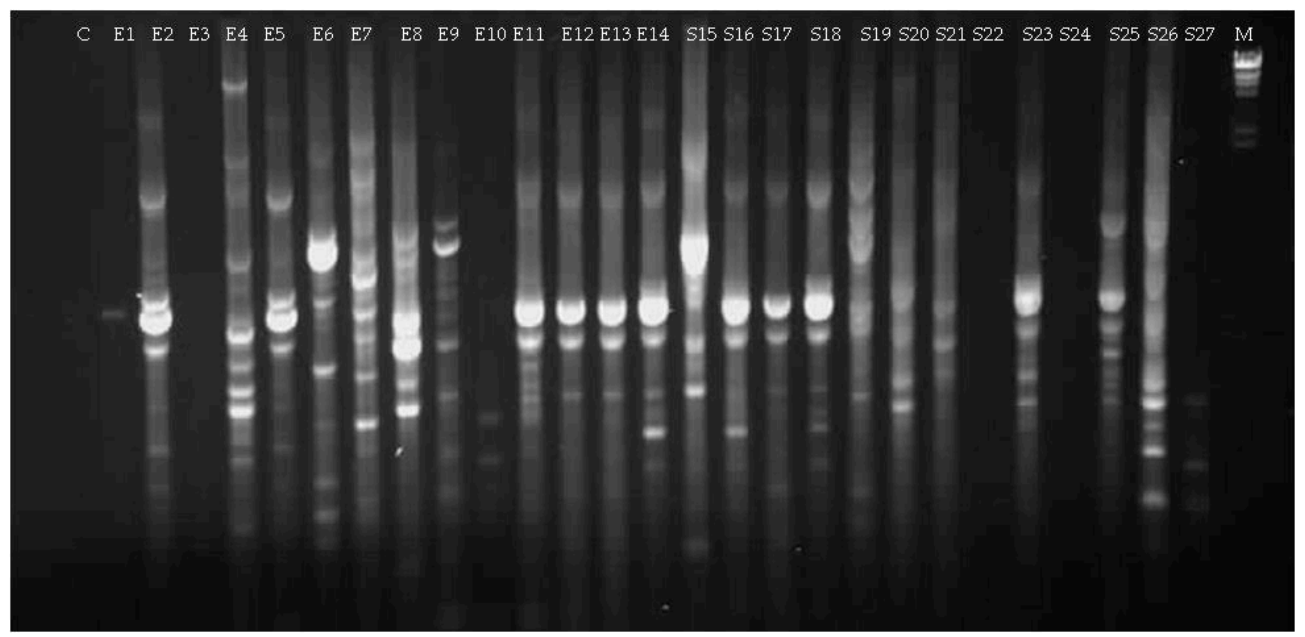

Figure A3. BOX-PCR profiles of isolated obtained from Elpida and Silverio seeds, were checked by electrophoresis in 1.5\% agarose gels stained with ethidium bromide that included a marker Lambda/Hind III.

Isolates E1 to E14 were obtained from surface sterilized seeds of Tomato cultivar Elpida, among them we selected for further studies E1, E2, E4, E6, E7, E8, E9, E10, y E12 (Figure A3). Isolates S15 to S27 were obtained from surface sterilized seeds of tomato cultivar Silverio and those selected for further studies were S15, S18, S19, S20, S21, S26 y S27 (Figure A3). The 16S rDNA sequences of isolates $\mathrm{E} 1, \mathrm{E} 2, \mathrm{E} 12, \mathrm{~S} 18$ showed that they were highly similar to bacteria that have been described as being pathogens of tomatoes and because of this they were not included for further analysis.

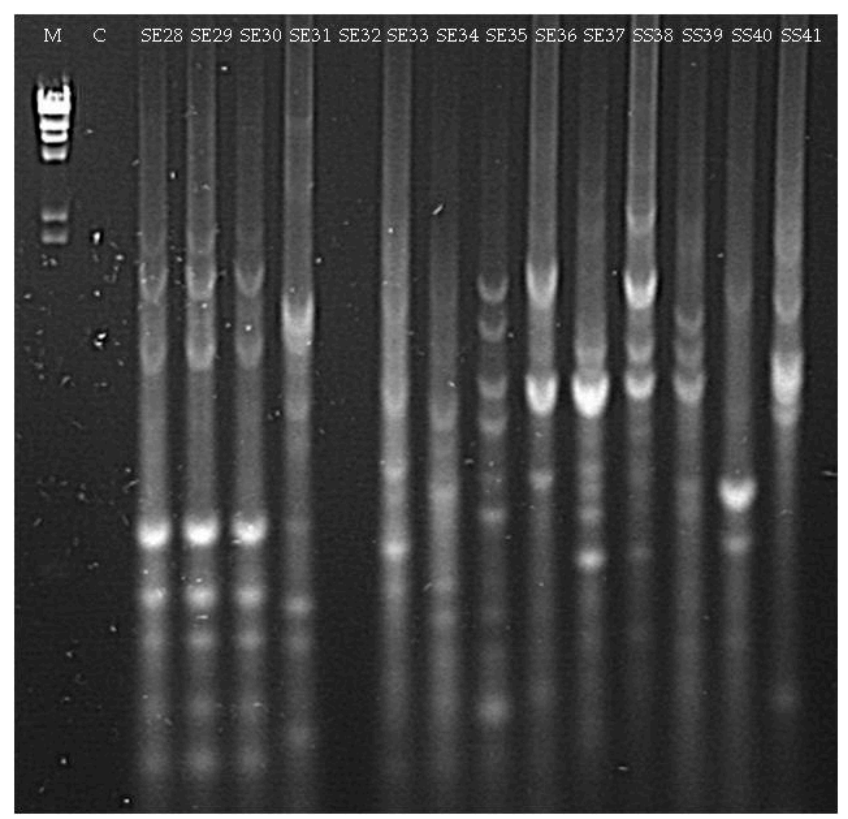

Figure A4. BOX-PCR profiles of isolated obtained from Elpida and Silverio seedlings, were checked by electrophoresis in $1.5 \%$ agarose gels stained with ethidium bromide that included a marker Lambda/Hind III. 
Isolates SE28 to SE37 were obtained from seedlings of tomato Elpida and among them SE28, SE31, SE33, SE34, SE35, SE36 y SE37 were selected for further studies (Figure A4). Isolates SS38 and SS41 were obtained from tomato plants of cultivar Silverio and were all considered for further analysis. (Figure A4). The $16 \mathrm{~S} r \mathrm{DNA}$ sequence of isolate SS40was similar to bacteria known as plant pathogens and because of this were not included in the following studies.

Finally, the strains: E4, E6, E7, E8, E9, S15, S19, S20, S21, S26, S27, SE28, SE31, SE33, SE34, SE35, SE36, SE37, SS38, SS39 and SS41 were considered to be unique among isolates and were identified by $16 S$ rDNA sequences.

\section{References}

1. Food and Agriculture Organization of the United Nations, FAOSTAT. Available online: http:/ faostat.fao.org (accessed on 1 June 2018).

2. Hallmann, J.; Quadt-Hallmann, A.; Mahaffee, W.; Kloepper, J. Bacterial endophytes in agricultural crops. Can. J. Microbiol. 1997, 4, 895-914. [CrossRef]

3. Hardoim, P.; Van Overbeek, L.; Berg, G.; Pirttilä, A.; Compant, S.; Campisano, A.; Döring, M.; Sessitsch, A. The hidden world within plants: Ecological and evolutionary considerations for defining functioning of microbial endophytes. Microbiol. Mol. Biol. Rev. 2015, 79, 293-320. [CrossRef] [PubMed]

4. Frank, A.; Saldierna-Guzmán, J.P.; Shay, J. Transmission of Bacterial Endophytes. Microorganisms 2017, 5, 70. [CrossRef] [PubMed]

5. Berendsen, R.; Pieterse, C.; Bakker, P. The rhizosphere microbiome and plant health. Trends Plant Sci. 2012, 17, 478-486. [CrossRef] [PubMed]

6. Bhardwaj, D.; Ansari, M.; Sahoo, R.; Tuteja, N. Biofertilizers function as key player in sustainable agriculture by improving soil fertility, plant tolerance and crop productivity. Microb. Cell Fact. 2014, 13, 66. [CrossRef] [PubMed]

7. Vejan, P.; Abdullah, R.; Khadiran, T.; Ismail, S.; Nasrulhaq-Boyce, A. Role of plant growth promoting rhizobacteria in agricultural sustainability-A review. Molecules 2016, 21, 573. [CrossRef] [PubMed]

8. Malfanova, N.; Lugtenberg, B.; Berg, G. Endophytic Bacteria with Plant Growth Promoting and Biocontrol Abilities. Ph.D. Thesis, Leiden University, Leiden, The Netherlands, 2013.

9. Turner, T.; James, E.; Poole, P. The plant microbiome. Genome Biol. 2013, 14, 209. [CrossRef] [PubMed]

10. Rosenblueth, M.; Martínez-Romero, E. Bacterial endophytes and their interactions with hosts. Mol. PlantMicrobe Interact. 2006, 19, 827-837. [CrossRef] [PubMed]

11. Hardoim, P.; van Overbeek, L.; van Elsas, J. Properties of bacterial endophytes and their proposed role in plant growth. Trends Microbiol. 2008, 16, 463-471. [CrossRef] [PubMed]

12. Ahmad, F.; Ahmad, I.; Khan, M. Screening of free-living rhizospheric bacteria for their multiple plant growth promoting activities. Microbiol. Res. 2008, 163, 173-181. [CrossRef] [PubMed]

13. Compant, S.; Clément, C.; Sessitsch, A. Plant growth-promoting bacteria in the rhizo-and endosphere of plants: Their role, colonization, mechanisms involved and prospects for utilization. Soil Biol. Biochem. 2010, 42, 669-678. [CrossRef]

14. Bulgarelli, D.; Schlaeppi, K.; Spaepen, S.; van Themaat, E.; Schulze-Lefert, P. Structure and functions of the bacterial microbiota of plants. Ann. Rev. Plant Biol. 2013, 64, 807-838. [CrossRef] [PubMed]

15. Gaiero, J.; McCall, C.; Thompson, K.; Day, N.; Best, A.; Dunfield, K. Inside the root microbiome: Bacterial root endophytes and plant growth promotion. Am. J. Bot. 2013, 100, 1738-1750. [CrossRef] [PubMed]

16. Nelson, E. Microbial dynamics and interactions in the spermosphere. Annu. Rev. Phytopathol. 2004, 42, 271-309. [CrossRef] [PubMed]

17. Ewald, P. Transmission modes and evolution of the parasitism-mutualism continuum. Ann. N. Y. Acad. Sci. 1987, 503, 295-306. [CrossRef] [PubMed]

18. Rudgers, J.; Afkhami, M.; Rúa, M.; Davitt, A.; Hammer, S.; Huguet, V. A fungus among us: Broad patterns of endophyte distribution in the grasses. Ecology 2009, 90, 1531-1539. [CrossRef] [PubMed]

19. Cankar, K.; Kraigher, H.; Ravnikar, M.; Rupnik, M. Bacterial endophytes from seeds of Norway spruce (Picea abies L. Karst). FEMS Microbiol. Lett. 2005, 244, 341-345. [CrossRef] [PubMed] 
20. Xu, M.; Sheng, J.; Chen, L.; Men, Y.; Gan, L.; Guo, S.; Shen, L. Bacterial community compositions of tomato (Lycopersicum esculentum Mill.) seeds and plant growth promoting activity of ACC deaminase producing Bacillus subtilis (HYT-12-1) on tomato seedlings. World. J. Microbiol. Biotech. 2014, 30, 835-845. [CrossRef] [PubMed]

21. Nicholson, W.; Munakata, N.; Horneck, G.; Melosh, H.; Setlow, P. Resistance of Bacillus endospores to extreme terrestrial and extraterrestrial environments. Microbiol. Mol. Boil. Rev. 2000, 64, 548-572. [CrossRef]

22. Truyens, S.; Weyens, N.; Cuypers, A.; Vangronsveld, J. Bacterial seed endophytes: Genera, vertical transmission and interaction with plants. Environ. Microbiol. Rep. 2015, 7, 40-50. [CrossRef]

23. Tian, B.; Zhang, C.; Ye, Y.; Wen, J.; Wu, Y.; Wang, H.; Li, L.; Cai, S.; Cai, W.; Cheng, Z.; et al. Beneficial traits of bacterial endophytes belonging to the core communities of the tomato root microbiome. Agric. Ecosyst. Environ. 2017, 247, 149-156. [CrossRef]

24. Bulgarelli, D.; Rott, M.; Schlaeppi, K.; van Themaat, E.; Ahmadinejad, N.; Assenza, F.; Rauf, P.; Huettel, B.; Reinhardt, R.; Schmelzer, E.; et al. Revealing structure and assembly cues for Arabidopsis root-inhabiting bacterial microbiota. Nature 2012, 488, 91-95. [CrossRef] [PubMed]

25. Sessitsch, A.; Hardoim, P.; Döring, J.; Weilharter, A.; Krause, A.; Woyke, T.; Mitter, B.; Hauberg-Lotte, L.; Friedrich, F.; Rahalkar, M.; et al. Functional characteristics of an endophyte community colonizing rice roots as revealed by metagenomic analysis. Mol. Plant-Microbe Interact. 2012, 25, 28-36. [CrossRef] [PubMed]

26. Bai, Y.; Müller, D.; Srinivas, G.; Garrido-Oter, R.; Potthoff, E.; Rott, M.; Dombrowski, N.; Münch, P.; Spaepen, S.; Remus-Emsermann, M.; et al. Functional overlap of the Arabidopsis leaf and root microbiota. Nature 2015, 528, 364-369. [CrossRef] [PubMed]

27. Romero, F.; Marina, M.; Pieckenstain, F. The communities of tomato (Solanum lycopersicum L.) leaf endophytic bacteria, analyzed by 16S-ribosomal RNA gene pyrosequencing. FEMS Microbiol. Lett. 2014, 351, 187-194. [CrossRef] [PubMed]

28. Weisburg, W.; Barns, S.; Pelletier, D.; Lane, D. $16 S$ ribosomal DNA amplification for phylogenetic study. J. Bacterial. 1991, 173, 697-703. [CrossRef]

29. Lane, D. 16S/23S rRNA sequencing. In Nucleic Acid Techniques in Bacterial Systematic; Stackebrandt, E., Goodfellow, M., Eds.; John Wiley and Sons: New York, NY, USA, 1991; pp. 115-175.

30. Schloss, P.; Westcott, S.; Ryabin, T.; Hall, J.; Hartmann, M.; Hollister, E.; Lesniewski, R.; Oakley, B.; Parks, D.; Robinson, C.; et al. Introducing mothur: Open-source, platform-independent, community-supported software for describing and comparing microbial communities. Appl. Environ. Microbiol. 2009, 75, 7537-7541. [CrossRef] [PubMed]

31. Quast, C.; Pruesse, E.; Yilmaz, P.; Gerken, J.; Schweer, T.; Yarza, P.; Peplies, J.; Glöckner, F. The SILVA ribosomal RNA gene database project: Improved data processing and web-based tools. Nucleic Acids Res. 2012, 41, D590-D596. [CrossRef] [PubMed]

32. Allen, H.; Bayles, D.; Looft, T.; Trachsel, J.; Bass, B.; Alt, D.; Bearson, S.; Nicholson, T.; Casey, T. Pipeline for amplifying and analyzing amplicons of the V1-V3 region of the $16 S$ rRNA gene. BMC Res. Notes 2016, 9, 380. [CrossRef] [PubMed]

33. Edgar, R.; Haas, B.; Clemente, J.; Quince, C.; Knight, R. UCHIME improves sensitivity and speed of chimera detection. Bioinformatics 2011, 27, 2194-2200. [CrossRef] [PubMed]

34. Hill, M. Diversity and evenness: A unifying notation and its consequences. Ecology 1973, 54, 427-432. [CrossRef]

35. Medina, R.; Gara, P.; Fernández-González, A.; Rosso, J.; Del Panno, M. Remediation of a soil chronically contaminated with hydrocarbons through persulfate oxidation and bioremediation. Sci. Total Environ. 2018, 618, 518-530. [CrossRef] [PubMed]

36. Surette, M.; Sturz, A.; Lada, R.; Nowak, J. Bacterial endophytes in processing carrots (Daucus carota L. var. sativus): Their localization, population density, biodiversity and their effects on plant growth. Plant Soil 2003, 253, 381-390. [CrossRef]

37. López, S.; Balatti, P. Closely related strains of Bradyrhizobium contained in commercial inoculates of soybean are identified by a set of PCR reactions. Genet. Eng. Biotech. J. 2012, 2011, 1-8.

38. Kearse, M.; Moir, R.; Wilson, A.; Stones-Havas, S.; Cheung, M.; Sturrock, S.; Buxton, S.; Cooper, A.; Markowitz, S.; Duran, C.; et al. Geneious Basic: An integrated and extendable desktop software platform for the organization and analysis of sequence data. Bioinformatics 2012, 28, 1647-1649. [CrossRef] [PubMed] 
39. Baysal, Ö.; Lai, D.; Xu, H.; Siragusa, M.; Çalışkan, M.; Carimi, F.; Teixeira, J.; Tör, M. A proteomic approach provides new insights into the control of soil-borne plant pathogens by Bacillus species. PLoS ONE 2013, 8, e53182. [CrossRef] [PubMed]

40. Medina, R.; López, S.; Franco, M.; Rollan, C.; Ronco, B.; Saparrat, M.; De Wit, P.; Balatti, P. A Survey on Occurrence of Cladosporium fulvum Identifies Race 0 and Race 2 in Tomato-Growing Areas of Argentina. Plant Dis. 2015, 99, 1732-1737. [CrossRef]

41. Alexander, D.; Zuberer, D. Use of chrome azurol S reagents to evaluate siderophore production by rhizosphere bacteria. Biol. Fert. Soils 1991, 12, 39-45. [CrossRef]

42. Castagno, L.; Estrella, M.; Sannazzaro, A.; Grassano, A.; Ruiz, O. Phosphate-solubilization mechanism and in vitro plant growth promotion activity mediated by Pantoea eucalypti isolated from Lotus tenuis rhizosphere in the Salado River Basin (Argentina). J. Appl. Microbiol. 2011, 110, 1151-1165. [CrossRef] [PubMed]

43. Bric, J.; Bostock, R.; Silverstone, S. Rapid in situ assay for indoleacetic acid production by bacteria immobilized on a nitrocellulose membrane. Appl. Environ. Microbiol. 1991, 57, 535-538. [PubMed]

44. Sorroche, F.; Spesia, M.; Zorreguieta, A.; Giordano, W. A positive correlation between bacterial autoaggregation and biofilm formation in native Sinorhizobium meliloti isolates from Argentina. Appl. Environ. Microbiol. 2012, 78, 4092-4101. [CrossRef] [PubMed]

45. Kloepper, J.; Beauchamp, C. A review of issues related to measuring colonization of plant roots by bacteria. Can. J. Microbiol. 1992, 38, 1219-1232. [CrossRef]

46. Guan, B.; Zhou, D.; Zhang, H.; Tian, Y.; Japhet, W.; Wang, P. Germination responses of Medicago ruthenica seeds to salinity, alkalinity, and temperature. J. Arid Environ. 2009, 73, 135-138. [CrossRef]

47. Bacilio-Jiménez, M.; Aguilar-Flores, S.; Ventura-Zapata, E.; Pérez-Campos, E.; Bouquelet, S.; Zenteno, E. Chemical characterization of root exudates from rice (Oryza sativa) and their effects on the chemotactic response of endophytic bacteria. Plant Soil 2003, 249, 271-277. [CrossRef]

48. Cottyn, B.; Regalado, E.; Lanoot, B.; De Cleene, M.; Mew, T.; Swings, J. Bacterial populations associated with rice seed in the tropical environment. Phytopathology 2001, 91, 282-292. [CrossRef] [PubMed]

49. Mano, H.; Tanaka, F.; Watanabe, A.; Kaga, H.; Okunishi, S.; Morisaki, H. Culturable surface and endophytic bacterial flora of the maturing seeds of rice plants (Oryza sativa) cultivated in a paddy field. Microbes Environ. 2006, 21, 86-100. [CrossRef]

50. Compant, S.; Mitter, B.; Colli-Mull, J.; Gangl, H.; Sessitsch, A. Endophytes of grapevine flowers, berries, and seeds: Identification of cultivable bacteria, comparison with other plant parts, and visualization of niches of colonization. Microb. Ecol. 2011, 62, 188-197. [CrossRef] [PubMed]

51. Hardoim, P.; Hardoim, C.; Van Overbeek, L.; Van Elsas, J. Dynamics of seed-borne rice endophytes on early plant growth stages. PLoS ONE 2012, 7, e30438. [CrossRef] [PubMed]

52. Liu, H.; Carvalhais, L.; Crawford, M.; Singh, E.; Dennis, P.; Pieterse, C.; Schenk, P. Inner plant values: Diversity, colonization and benefits from endophytic bacteria. Front. Microbiol. 2017, 8. [CrossRef] [PubMed]

53. Simon, H.; Smith, K.; Dodsworth, J.; Guenthner, B.; Handelsman, J.; Goodman, R. Influence of tomato genotype on growth of inoculated and indigenous bacteria in the spermosphere. Appl. Environ. Microbiol. 2001, 67, 514-520. [CrossRef] [PubMed]

54. Adams, P.; Kloepper, J. Effect of host genotype on indigenous bacterial endophytes of cotton (Gossypium hirsutum L.). Plant Soil 2002, 240, 181-189. [CrossRef]

55. Franco-Correa, M.; Chavarro-Anzola, V. Actinobacteria as Plant Growth-Promoting Rhizobacteria. In Actinobacteria-Basics and Biotechnological Applications; InTech: Rijeka, Croatia, 2016.

56. Sangthong, C.; Setkit, K.; Prapagdee, B. Improvement of cadmium phytoremediation after soil inoculation with a cadmium-resistant Micrococcus sp. Environ. Sci. Pollut. Res. 2016, 23, 756-764. [CrossRef] [PubMed]

57. Prapagdee, B.; Chanprasert, M.; Mongkolsuk, S. Bioaugmentation with cadmium-resistant plant growth-promoting rhizobacteria to assist cadmium phytoextraction by Helianthus annuus. Chemosphere 2013, 92, 659-666. [CrossRef] [PubMed]

58. Vílchez, J.I.; Niehaus, K.; Dowling, D.; González-López, J.; Manzanera, M. Protection of pepper plants from drought by Microbacterium sp. 3J1 by modulation of the plant's glutamine and $\alpha$-ketoglutarate content: A comparative metabolomics approach. Front. Microbiol. 2018, 9, 284. [CrossRef] [PubMed]

59. Ulrich, K.; Stauber, T.; Ewald, D. Paenibacillus-A predominant endophytic bacterium colonising tissue cultures of woody plants. Plant Cell Tissue Organ Cult. 2008, 93, 347-351. [CrossRef] 
60. Cheba, B.A. Diversity, Phyto Beneficial Activities and Agrobiotechnology of Plant Growth Promoting Bacillus and Paenibacillus. In Proceedings of the ICBB 2016: 18th International Conference on Biotechnology and Bioengineering, Stockholm, Sweden, 11-12 July 2016.

61. Grady, E.; MacDonald, J.; Liu, L.; Richman, A.; Yuan, Z. Current knowledge and perspectives of Paenibacillus: A review. Microb. Cell Fact. 2016, 15, 203. [CrossRef] [PubMed]

62. Timmusk, S.; Grantcharova, N.; Wagner, E. Paenibacillus polymyxa invades plant roots and forms biofilms. Appl. Environ. Microb. 2005, 71, 7292-7300. [CrossRef] [PubMed]

(C) 2018 by the authors. Licensee MDPI, Basel, Switzerland. This article is an open access article distributed under the terms and conditions of the Creative Commons Attribution (CC BY) license (http:/ / creativecommons.org/licenses/by/4.0/). 